University of Rhode Island

DigitalCommons@URI

Open Access Master's Theses

1964

\title{
Counseling Role Perceptions of United States Navy Chaplains
}

Thomas Barclay Uber

University of Rhode Island

Follow this and additional works at: https://digitalcommons.uri.edu/theses

\section{Recommended Citation}

Uber, Thomas Barclay, "Counseling Role Perceptions of United States Navy Chaplains" (1964). Open Access Master's Theses. Paper 1756.

https://digitalcommons.uri.edu/theses/1756

This Thesis is brought to you for free and open access by DigitalCommons@URI. It has been accepted for inclusion in Open Access Master's Theses by an authorized administrator of DigitalCommons@URI. For more information, please contact digitalcommons-group@uri.edu. 
COUNSELING ROLE PERCEPTIONS OR

UNITED STATES NAVY CHAPLATNS

BY

Thomas Barctar uber

A TEESIS SUBMITED IN PARTIAT FULPILIMENT OF THE

REQUTREMENTS FOR THE DEGREE OF

MASTER OF ARTS

IN

- EDUCATION

UNIVERSI TY OF RHODE ISTAAND

1964 


\section{ABSTRACT}

Thi. atudy is an exploxation of the pexcoption of councelor role held by nevy chaplatns. The olse of the Havy, Ite comitments as a power for peace, Ite concern for the individual as eseontial to the defense framawork all lupinge direetly or Indireetly upon the ohaplais as councelor. How he viewe his role in the 21ght of recent dovelogaents in poyohologleal reweerch and contanporary theories of paychotharapy is of utmost importanse to the navy in terms of effective work with Ite pareanal and Ite emphasle upon character and Ieaderehip edueation.

Some of the dyamie fectors revelent to the chaplafn's role as councelor axe excmined in this stady. He is viewed whin the structure with which be warks, the pereonnel with whom he serves, and is glven a view of himself as he understande his function in this aspect of his naval aldetry. While there are some alallardtie between olvilien and ailitary counceling, there are valid differences whlch warrant study and understanding. The etrict authoritarian environant of the navy, Ite geographioal alvaroity and mobility present many case londs quite different in number and acope from thoes encountered in ofvilian Ilfe.

The atrudy of the velue-structure of naval parsonnel reflect the precent brealedown of absolute values as well as the dwindifg influence of rolfglon among today's youth. 
This roveals a noed for a deaper underetanding and acceptance of thos who are potential cllent: of the chaplain.

In developing this thesis, an objective-type ourvey queotionnalre was prepared to gatm incight into the foelinge of nuvy chaplats concuming many acpects of the councaling role. Iteas in the ourvey were concerned with underetending of counselfing tockniques, Intenutty of equecling problem areas, Level of acadenic training, and andervtanding of the nacure of the on-to-one ralationhip. After preteoting the questonuaire on graduate students engaged in coranselor education at the Dniversity of Rhode Ieland and a group of reserve ohaplains at attonding a cenoltivity seminar at the Choplaino school, Wowport, It wa sent to chaplains earving on novy and marine coxp stations on the eat coast. This

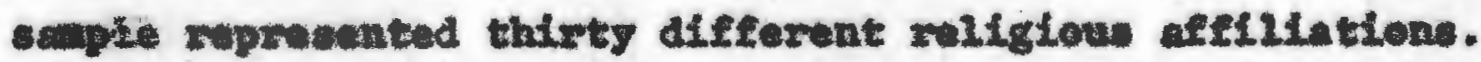

A high perecntage of returns (85 par cent) were recelved from this survey, Results revenled; (a) a cerlous Interest in the function of combeling evidenced by the high percentage of paestionnalres returned; (b) the awareness of an Inereasing need for more in-ourvioe training both acadentc and clfnical; (e) the higher rank and greater exparlonos correlated directy with e enper understending of the dyanice of the halping relationohtp (d) responses fron chaplatin of four religicu bodies showed ignifteant differences in practice, (e) the total raponse showed navy chaplains aurveyed to be more "coungelermeentered" than atther the graduate 
studente or reserve chaplains who cerved a a control group. Recemandation arleting frem this stoudy aro made tor Impovenat of comealor proparation and practed in the navg ehaplatns eoxpes. 


\section{ACKNOWLEDGEMENTS}

The miter wibhes to expreas his deep gratitude to Dr. 8. Marvin Rffe, who took time from his bagy and crowded sebodule to give encouragenent and aseletance In developing this study. Without his holp this thesie could not have been coupleted. Sincerv thanks are further extended to the other nembers of the theola conaittee, Dr, Charles R. Dolan and Dr. WIILen Young for thair valnable auggestion and recomendations, and to the Nevy chaplains who cooperated In this study. 


\section{TABLE OF CONTENTS}

CRAPTER

PAGE

AGKOWLEDGEMBITS .................... v LIST OF TABLES ...................... vill

I. PREVIEW. .................... 1

The Problea................. 1

statement of the problem. .......... 1

Importence of the etrody .......... 3

Naval Fundamental Factork. .......... 6

Dithaction between Maval and efvilian Life. 7

Pulvlleged comanication. ........ 10

Definition of Counseling . . . . . . . . 11

II. TEE COUNSELIMG RETATIONSHTP. .......... 13

Heed for Comnoeling in the Havy. ....... 14

The Nature of the Relatlonohip......... 15

Cormalling and Religion.......... 20

Pabtoral Counseling Yovesent. . . . . . 24

Exiotential Reychotharapy and Counseling . . . 28

III. THE NAVY CLIENT. . . . . . . ....... 31

Velue Structure of Naval Pertonnal ....... 32

Raval Personnel and College studente. . . 33

Home and Fandly. ............ 35

Health. ............... 37

Religlon. ................ 38

Financlal socurlty. ........... 40

Reeulte of Valne Study ............ 43 
IV. METHODOLOGY. ............... 46

the Survey quatlonnalre... . . . . . . 46

v. PREsentation of data .............. 51

Over-all Remponse by havy Rank ........ 51

Compartson of Beligtors Deferencea. . . . 53

Analyelo of questlonnalre. . ........ 54

Counsellng Bactore. ........... 54

Freguency of Case-type Laeds. . . . . . 57

Level of readenie Tralning of Chaplains. .. 58

Divereity of Definitlons of Counceling. . . 61

V. SUMMARY AND CONGUUSTONS. . . . ........ 66

sumary. . . . . . . . . . . . . 66

Recomandations. ............. 69

BIBLTOGRAPHY. ................. 73

APPENDIX A. Copy of survey Quentionnalre . . . . . 76

APRaMoIX B, cowering Ietter oent with guetlonnalre. 78

APPENDIX C. Sumary of Beaponees to guetlonnalre,

Part 1. . . . . . . . . . . . 79

APPENDIX D. DLetribution of Raponses by Church

and Rank ................. 80 


\section{LIST OF TABLES}

TARE

PAGE

I. Valees Military Parsonnel at quonset Polnt Coneidered Nost Important in Rank Order. . . . . 34

II. Sources of Iffe-Satiafaction of Collage strudents. ................ 35

III. Number of Questionnalres Sant Showing DLetribution by Navy Rank and Total Maber in Eech Rank of Chaplain Corps ........... 49

IV. Mear, Range and Total of Direetive and Congruence Scores of Chaplafme Tabulated by Mavy Rank. . 52

v. Maan, Range and rotal of Directive and Congruanee Scores of Chaplative of Pour Different Cwrehes . 53

vI. Typea of Probleme Listed in Rank Order Most Frequentiy Encountered by Cusplains. ...... 58

VII. Graduate Level Iraining in Couneeling and Related Fieldo Reported by Chaplaino. ......... 59

vIII. Sumary of Defiultions of Couneding Given by Chaplains, Ranging from Directive to kon-diredaive 61 
PREVTEW

This thesis is a study of the counoulting role as understood and practloed by 0. S. Mavy Chaplains. The


the of of the neval exteblichunt, and the ooope of It: operational concerm make It of vital lutexeot understand fast how wavy ehoplain view thelr tunetion a counselor. While some attantion lo glven to the beokground and valusstructure of the navy cllent, pxtmary emphade te on the cheplati" andaretanding of the ceunseling ralationohlp. An effort will be made hare to delinoate and evaluate the bacle Eactors relating to the nav chaplain's funotionfing In and proparation for the vork of ceaneding. Some conslderation 111 be given to the acadale training of ebaplaine, mubseqnent to bis graduation fros sewinary, the nature of their counseling load, and how the chaplain viowe hinaele a. counselor.

of hie many mesponelbilites in the nav, parhaps no function perforwed by a obplain denends greater preparaLon, Judgmant and ability than does oounouling. Cartalniy tew, If any, of his activities could be wore important. The problews conting to his attention are both varied and gute numerous. The navy chaplatn holds the posttion as one in the alltary organiation the has "privileged commatcation." 
This provides asaurance that a councelee's confldence oll not be vloleted. It provides a secure elimate for the beicle anxioty in the mind of 'a counselee who neede scavone with whom bo can talk troely and coneleantlally. The novy counselee ccepte the chaplain as a nember of the "twan," and reoogaises that he is equipped with the attribute to be of persenal or apiritual help w thout beacuing a threat to his mottional socurlty. The chaplain 18 constanty avallable and has the enique Ereoden to mingle with any and all ranke from the foun-otar adniral down to the seeman recrait.

Soue convideration wil be given to an explexation of the adequacy of proparation of the active duty ohaplain for this major function of his naval minletwy. The clegree of inportanes thoologieal centnaries plece upon acadenic and elinteal truining quite poesibly is reflected in the practec of thair graduates. Within the Navy a eall muber of cheplaine are chosen each year for postradunte training-ton have been selected for the yex 2964-1965. Tet this progran reache only a very anall pereentage of the total oerving on astive deth.

Another constderation is an exunfuation of the differences which may exiet between alvilian and naval counceling by olergyua. of imprtance bere are the enviroument and comituments of tha navman, the Mav's role as a power for peace, and the posttion of the abmplain within the structured allitary establidhant. 
A thind objoctive of this study it the pooulble revelation of counceling paxeptions exioting in a contiman Eron authoritative-dreetive to ponileatre-non-direativ. The therapeitte nature of the comaseling procese ie ultimately concerned vith the perseption of combulor role held.

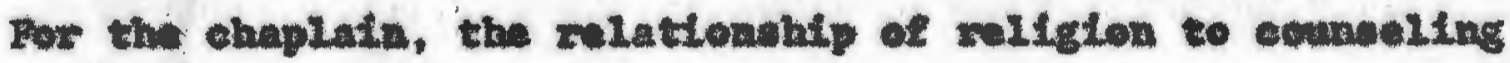
Le most importent and may present probleme of ollont-manipunaLon, Indoctrination or Jadgment in the relationihtp.

In the Uaited states Nevy today, thare are more than aive hundred ehaplains sexving on active duty. They ropresent

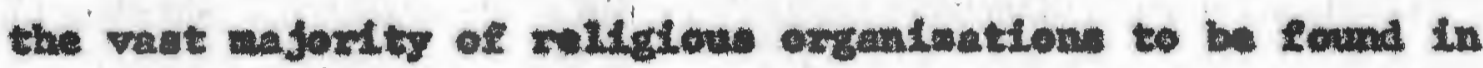
this nation. Thaly parich is compoed of over one allilon untformed pareontuel of the Nevy, the Coast Guard, the Marime Corps, and the dependente of thene mervices. It is an Intwrational park, tor thetr parlohoners are ceattered all over the world. The work of the avaplatn in guite variod.

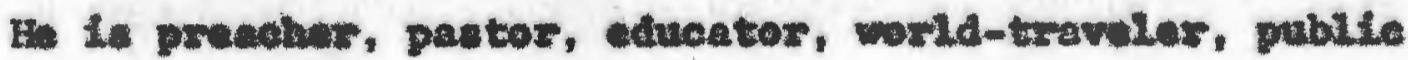
roletione axpert, coungelor and be exupliftes these proxogative even under the most adverwe conditions. Decause

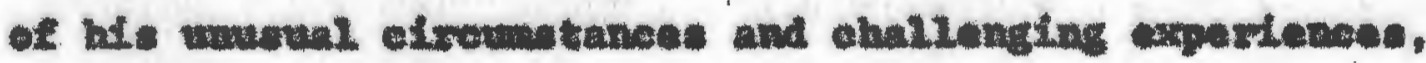

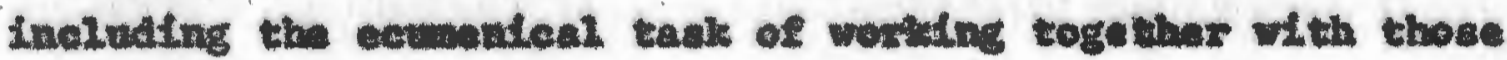
of varled Lat ths, the motto of the Chaplatas' Comp has betese "Ceoparation without Comproate."

Conalsulored by the United stateo Governant as an aftear, the Hav Guplain is the repmeentatu of his

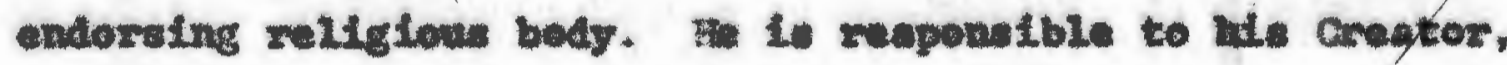


his churoh, his cemanding efflcer, his ohtprates and to the American people for the falthiul performance of duty. In a way, he is the pereonal repreeontedve of every fandig in the United states. His reoperatbility extends beyoud his own chip or station to ewry home ropretented aboard.

This study is proposed in reeogultion of the fact that the ned for excellence in counesling is fital. CounselIng is one of the wost inportant appecte of the chaplatn's funetion. It is a changling prefeeston which mat contimaliy exendine 1te standards of proparation and preforwance to escure the highest level of performance poeclble. As a profentonal function It it belng re-defined and clarifled by swoh organisutions as the Amarican Poychological Acoociation and the Amorican Pereonnel and Guldance Mesoolation, The Nationl Dafense Education Act of 1958 gives evidence of the concern of the goverment to ratee the etandards of counsoling and guldanes through its combeling lacttute beld in a nuber of univerafties each yeax. The reeognition by the Navy of this noed is refleoted in its prograns for pootgraduate otudy, couneoling and loederahtp seminare for chaplatno.

An inareasing number of thoologieal seatnarles are ctroalng and inoluding in their curricula clialcel and acadente training in couneling and related flelds. How chaplains, presentig on active duty, percelve their counceling role in the Lght of these recent developents is of critleal Importance to the vavy in terme of effective work with Ito 
pereoninal and its aphavis upon Ito Charecter, Education and Ladermip prograns.

For many yeare there has been the growing awaxenese by the Leadere of our nation that the total mesourees of fmertea are compoed of the strungthe and weaknesses of Ite Individual atelean. It a chaplain of the Nay, who deale with individuale and thoir probleme, is to meature up to his reeponalbilities to the Anerlean people, to his govemment, to his ehureh, and to the Individual who beeks or needs his help, be mast be ale to understand the noeds and requirement: of those the cona to him.

Man is today rasohing out in an attempt to conquer apace, and perkaps has the knowlodge, as wall as some of the inetrubente to ahleve this goal. But it is beconing ovident that wan hinacle lo otill the wost esoential element in any viatory achleved. In apte of the teobnologieal advances and mochanization of todey which tende to doperwonalleo man in his drive lor progruas and rletery, Individual revponalbllity does not decrease. In fact, Individual renponsibility Inereaces under these condition for, "tactloal advanees and the poodbilftes of the melear age notwithotanding, It is wan who will etermally rmain the ecesntial Ingrediont to auccesstul maritime oparations. ol

Wh the edvent of the melear powerve cubmartine and airereft earrier, it appears that Amoriea's naval corces will

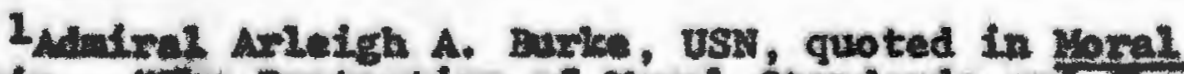
Isederahip. win Frotection of Moral standards an CMaractar Ecticazion Prograx," U. S. Navy and Marine Corpa, Navpers no. 15890. 
remain large for the forveceable future as the dengers

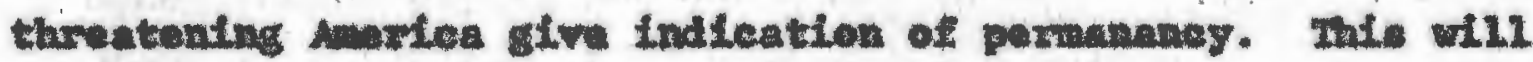
contimes to reeult in laxge mumbers of corvieman, depondenta, and in tio a laxge miltery alumi. As may servicenon mary and tom candly wite whle in oervies, thair thinicing patteres w11 affect future genorations through their ehlidren. Bcause the chaplatn is charged, vith the corangling zole during woh ortuleal stages of individual and national LLe. It Is most important that he mderstand bis tanotlon. The wore effectlve his couneling beconas, the better atrice ha will wender to the Individual, and ultimately to the natron. There are factor fundamontally Inharent in the Armad Forces whleh are vitul conalderatlons for connoeling vaval

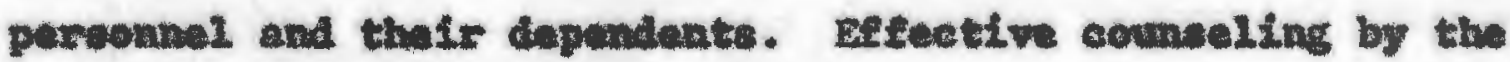
navy chaplatn mat neogonias and understand these elements Whoh may do woh to detannine the suecese or salluxe of ble role as eovaseler.

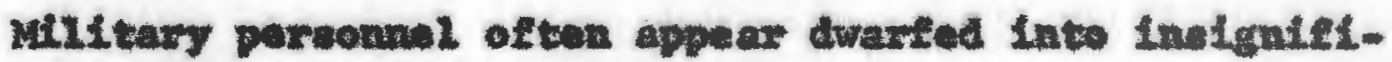

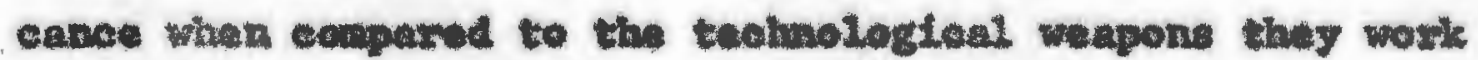
with and control. Dor from the researeh Laboratorles, developwat centers, and pamafecturing plont merge hight ceaplex equiparat neceseary in this nolear age. Yot these Intricate weapons must be mastred or ramain welese. It has been woll atated that:

the penetrating of of redir is revealing only as it gives range to man' natural sight. The continent-hurdilng electronic commanication aystems. 
give no Information excopt as they add araplification to nen's volces and sensitivity to their hearing. The superconic opeed of aireraft is the new stride of wen's lega. The range of gulded nissiles and the power of nuclear weapons are an extension of the thrust of their fists.2.

Tume the one inalopenelble element in the eftective

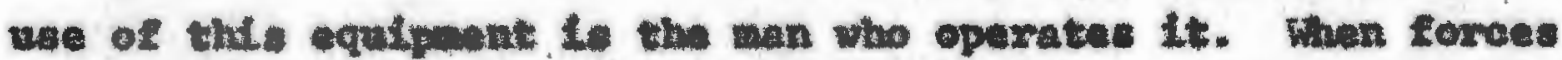

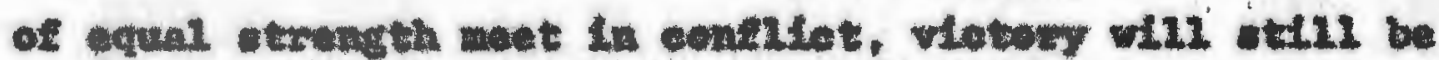
wh the men whe are otwong in opirit and posees high morale

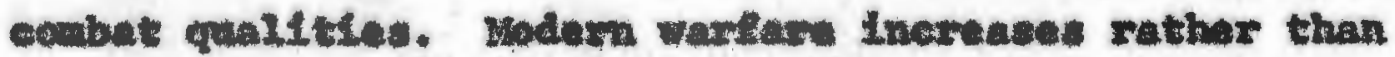

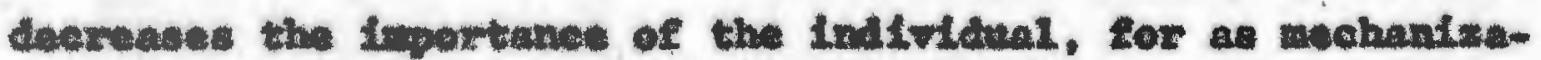
Llon Inotwaces, Job rewponulbillty inereases at an even Latrex rate.

Whlle thare is ainilartty in wany respects between elvilian enploper' uthisation of personal and that of the naval comander there are obse tupertant difterences, which may enter Into a comaling relationchip either directly or indirect2.

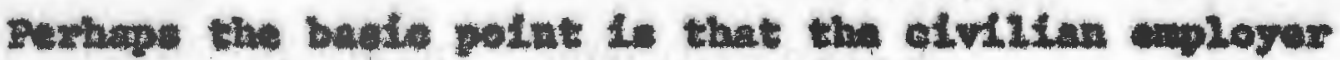
does not have "focmand atthordty." Tht wans that he does net represent gowarmantel axtworlty to entoree lan whereas

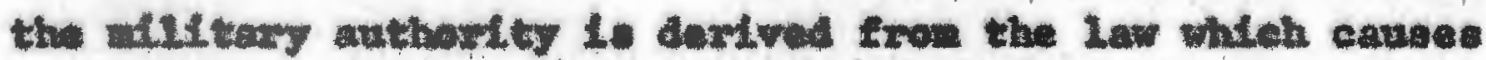
hin to be ag agent of the goverwmant. Sinoe the eraployer Ls Ifmited by apoutele eondftion of the exployed's work or rnton, his oncern sor the velfare of htl employe is aleo Linfted by law or cuttca, and be ha little or no anthority

$$
\text { 2rut. p. } 2 .
$$


over his pople from the elose of the working day until porte beglns the next morring. In contrast, the naval authority is centimave exound the eloak, so that interwot and concern L. not Iinted by a woxtudy. All activitfes affecting the Eltaese and readinens of pereomal to peirform naval dutiss are inherently within naval sapponalbilty. A comon caylng In the Navy is that a man is on duty twanty-20ur bours a Any, ooven daye a weak?

Another vital dietinction between eivilian and naval Lfe is the often eontrasting environmants in which they wopk. In Iew altruation does a eivillan aployar onder or pleee hie aployees in poulthow of twinent danger of Infary or death. Where ouch appeare necesary and yat havandoas, It is libely to be epedfleally voluntarliy undertalun for a correopondingly greater reward. In contract, naval wather t5 kequires that, at times, wen be placed in posttions of extreme hasard, and ocenolonaliy this is done as a matter of plain duty. Thu everyalng that way mean the Afferenes between suceess and fallure in cembet, and betwoen a man living or dying, falle within the concern of naval Life and Ite anthoritles.

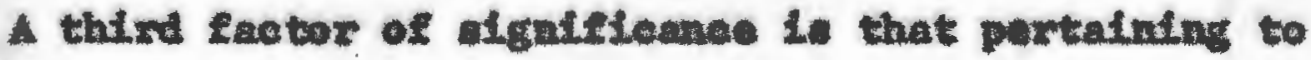
wlltary 2as. Ariminal law ceaks to protect ceatety frow irreoponatble menbers and thelr danaging actione, whereas alltary law require that its members not only do this, bot alco that all wat odhore to 1 te authoritarian etructure. 
Iwas, the clviLian "rghte" of "colling ofe the bowe,"

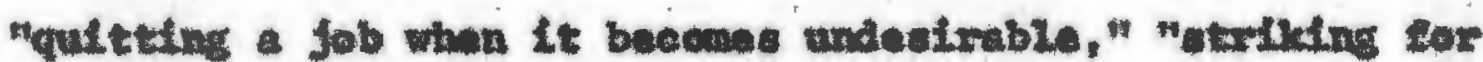
batter woxilug eonditions and walluting off the Job" are, by

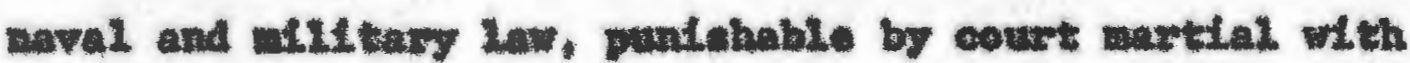

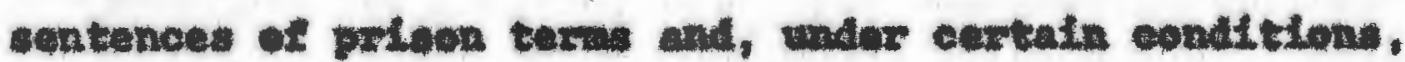
death. Watle thase are not dottned as exfmes by ofvll Low,

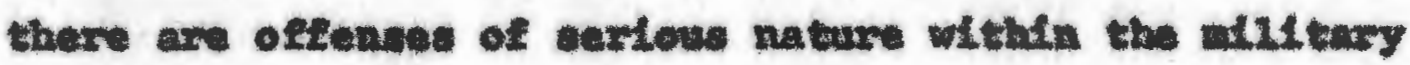
freanomork. It mat tharefore alwayn be rumumbered that

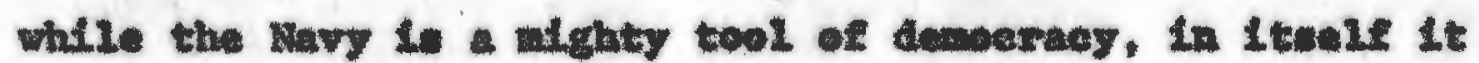
1. not demoeratie.*

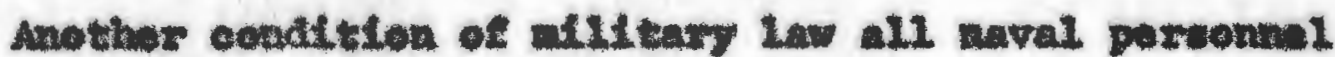
are subjected to It the addtonal dimonaton of making puatohable "conduct mbeoculing an offieer and a gontleman" as will as "eonduat of a matare to bring divercelt upon the Araed Forees." which if alflaront than the language found In wost alvil codes. Thas beemes of 1 to atruature the Ravy



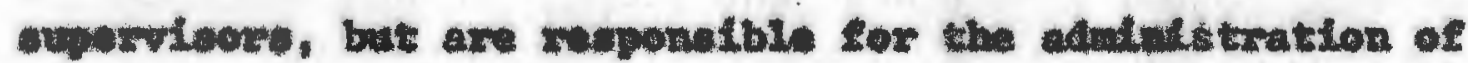
alleary juntea. 3

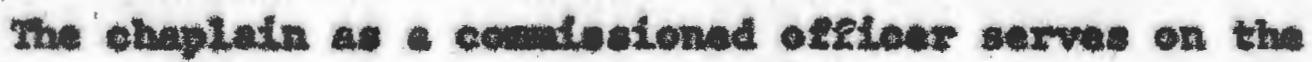

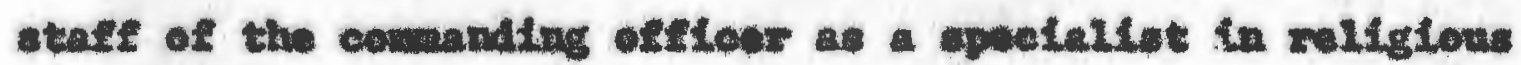
and morel attare. He to charged with many obligatson in the pertomance of his sole as a clergran in unteom, and among thee 10 that of counedor to both onlieted mon and

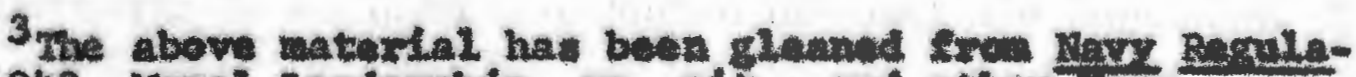
tions, 1949, Moxal Ieaderohlv, op. elt. and other wavy pubtications. 
offlcers as well as their, dependents who deeire or need his services. Different from his civillan countexpart, the chaplain mast also serve those who seek his escletance regardlese of their roliglous afflistion, for he 1 also a public ofetelal by compitation as well as a elergyman by ordination. 4 "Privileged communication" is another important factor pertinent to the counseling role of the chaplain. A comountcation received by a chaplain in the course of a panttentclexgyman relationship way not be divulged by the ehaplain, and he cannot be required by court-martial proceedinge to reveal any information learned in this manner. As counceling 1. a "one-to-one" minlutry, it is that olearly covered by privileged ecmunieation.

While some atates have laws providing such privileged commuication to the elergyman-pent tont or clorgyman-elleat reletlouship, othere do not. The Mamal for Courts-yertial, U. S., 1951 etates this rght for chaplains. 5 Firot defining pHilleged commanication as a "communteation made as an Incident of a confidential relation which it is in the public interest to protect. . ${ }^{6}$ It continues by declaring, - also privlileged are eommaleations nade between a preon cubject to ailitary law and chaplain, priest or clergyen of any denomination ande in the

\footnotetext{
4he Chaplains yamal, NavPare 15664-B, references Ilsted in rootnote numb 30 .

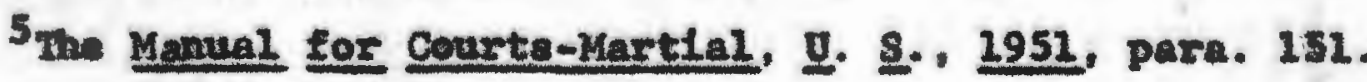
6Le. elt.
} 
relationship of penitent and chaplain,. . - elther as consience. 7 of religion or concerning a matter of

One authorlty, writsing in the Navy Chaplaine Bulletin, states concerning this matter: 8

Ho chaplain can atiafactorily fulfill his offloe unlese men know that communications can be mede to him whout fear of disclosure. Upon the chaplain Ealls the responsibility of correct advice to offenders who confess their misdeeds to him; but when such a confession has been received by the chaplain he need have no fear that the law will require its disclosure if he Is called as a witness.

It is not felt necessary to enter into a detalled delineation of the present day schools of coureling as thay are very well defined in present day literature on thio subject. Therefore, for the purposes of thil thenle, the following underatending of counseling is considered balle. Counceling is, first of all a relationohip. This to more important than any technique or methodology. It is a reletlonahlp between two people, in which one accepte, reflects, capathites, and clariftes the feelinge of the other leading the other or both to celf-growth, a realiatic knowledge, and development in a beneficlal direction. It is a relationohip that otriwe for greater self-understanding and greater selí-acceptance on the part of both councelor and cllent. In order to reach these qualties, the relationohip mast be ellent-centered to the extent that the cllent may have the

\author{
7 Ibld. P. 285. \\ ${ }^{8}$ Jane $*$. Grant, "The Pondtent-Clergyan Privllege
} In Miltary Law," Pavy Gaplatns Bulletin, Pall 1959 (Navpare 15020), P. 11 . 
freedom to reveal his feeling without tear of fudgant or censure by the counselor. It is truly a parcon-to-pereon relationohip, a genuine experlonce after which both councelor and client may be changed. 
THE COUNSELING RELATIONSHIP

It Le widely recognised that there exist certain basic neede of a peroon which wust be wet if one is to find swocess, a sense of well-being and bappluses. If these are not met, llfe tends to dinintegrate. A sense of adequecy and self-aswuxance beced upon developed velile, lanowledge and Vital interests makes for aelf-rellanee and indegandepree is well al alding th the oolving of life's problens. Because the preparation of the full life includes a reallation of mature reoponetbilitles, counceling is an Indiapensable role of the navy chaplain. As ouch it has a valld goal, that of holping to exfect ${ }^{\circ}$ mature and secure individual who w11 live wth moral integrity in peace and hazmony with himuelf, his netghbor and his cod. $n$

This counceling seponolblifty mut recognise that the whole individual reoponds In every uituation as a whole pureonal1ty.

Social developant, far frem botns influenced solely by precept or fact as wuch, Le a process of growth, physical and amotional, as well as inteliectual functioning, and the es three are interdependent.10

\footnotetext{
${ }^{9}$ per van Only, o. S. Navy and Marine Corps Character Guidance serter, 1 , 1 .

${ }^{20}$ Carollne B. Zachary, Detton and Conduat in

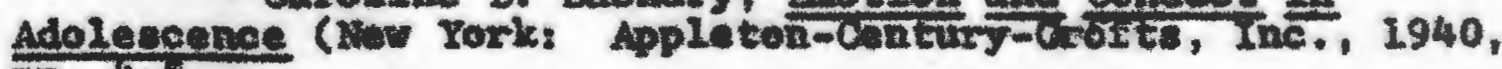
pp. 4-5.
} 
Since youth forns the larger part of the navy populathen, in this an ere of conflict in the atruggle for alfsealisation, peroonal, olliful belp is often needed to provent or correct Inadequate of undesirable development. Numerous factors of present day life lepose great atrain on the emotlonal Ite, eapeolally in the formative yeare of late adoleccence, which regulme preciee decleton. Yet preaent day Ifving conditions often seen to rule ow poditive and absolute otandarde so that each mast declde his own course of cotlon. Mequate standarde for a sense of securts, celfexprestion and self-deteruination cannot be onecestully imposed eron whout, bat mat becose basic to the Individual if they are to be valld.

Naval pexaonal and thatr depondentes, Ilke clvilan porsonnel require reoggition and status, regpect and ooctal Intereotlen, securlty and group aceptance, achlevmont and euccess, happlaess and frecdos. These are to be dectred and otraggled for in opite of the stern athorltaxian eavironment and atriet diecipline of the navy. It is the need to obtain thewe fectore that results in couplexce in the poychic Iife between aggreselve and security-making cetivitio which may wall ereate neurotic behavior patterne or cmotional confliete. Whare the chaplati as a counaelor ha a ouftiofent peyohologieal uaderatanding and akil, thare will be referred to hin counseling aftattons involving a wide varioty of problems. Many of the probleme require a reorlentation of 
outlook by the counselee rathor than a reedjustmant of cireunetances. Maler has rightly seld,

- . the business of transforming a human being is not aimple prepees. It dewands a certain optimien and patience, and above all, the exclusion of all personal vanity, elnce the individual to be traneformed is not in duty, bound to becom the object of another's vant ty. Il

In ho role as coungelor, the chaplain discovers that comeding is a science as well as an art. He meallzes that he 1o not exempt fros the disetplines required of other effective countelore. The effectivenase of his work depends upon a mastery of the sane knowledge and dymantos of hyman pareonality. He therefore ought to seak to wtilige the selentlete flndinge and ineights of othare as well as developIng hle om perwonal consept of role in the light of these. A oueceseful development in sound cowneding philosophy and techniques requires the tested precese of strady and eritical celf-exenination.

Counecling takes place in a relationohip between counsalor and ollent. Relationohip, ollent and counclor-all are Importapt and must be studied. But the most important of thase frem the potnt of thposving ocwaneling is the counselor, for we have aceses to onureelves. If we change or grow, we ateratioally ohange the potentialitte in the relathonohip and therefore, the postbiltules of belp for the nllont.

11 Alfred Alier, underetanding Bunua hature (Oreamrleh, Conn.: Favett Publication, Ino., Pwinter Booco, 1957), p. 21. 
Espectally in the role of counseling, as nary ohap-. latns, It is felt that learaing about one's om ettltades is the wost subtle and wout important aspect of the task. LearnIng about the navg ellent, his immense varleties and wique Indiviualities is of groat importenoe. Bat one nay know all about the ellent and atill be wable to enter into what Rogere calle "e helpling relationulp" wth him. There fast be a genuinones that comes only from penctration into ond '

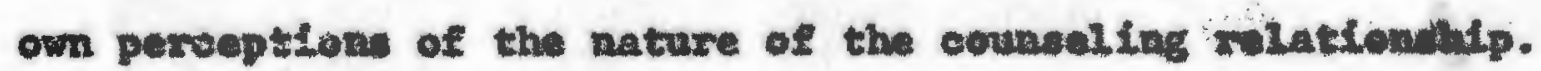
There are as many approaches to the counceling reLationohp as ther are counnelors. However, all would agree that the cesired outcone of counseling is to belp the counelee. Arbwakle offers a nuber of goal that be feels should not be coneldered anong the objectives of counceling. Be Hghtly asects that councelor colution of elient' problen may belng temporary rellef but does not bolp change the causes of bie problens. Hkewles, client atisfastion or happinese should not be a prinary objective nor belping the cllant to conform to or adjugt to soctety, which may not produre real seourt ty or independenoe in an Individual. Arbuckle conalder the objectives of counceling to be based on certain prinelplea aveh as: (1) client need rathar than counoelor need, (2) selentifie rather than centinental obJective whloh trive for reallty rather than faled auport, (3) that the councelor operate with a concept of a relative world in which we live, rather than an absolute world, 
and (4) a strong belief in the cepablities and atreagthe of a pereon. 12

The Hays Chaplain, ${ }^{13}$ In a brief section on the chapLatn's functlor as a councelor, quotes many leading men in this fila. Couneling definitlons quoted to give an overall view of the sort, range from Kays "any deop underetenAing between pereon which rewulte In a change of pareonalt to Wrenat

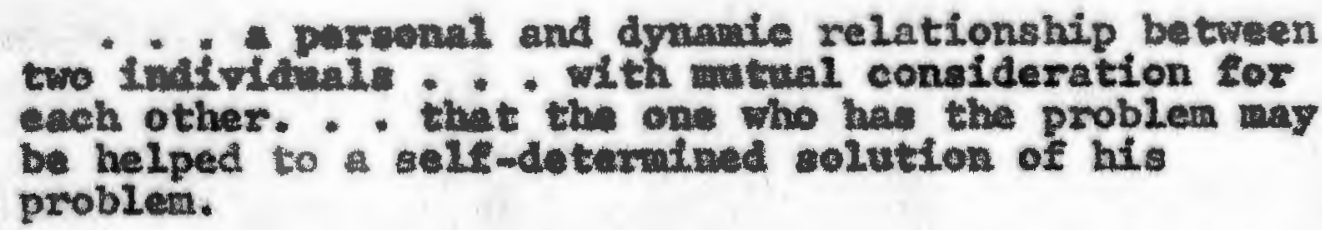

A eurvey of the three gonerally reoognied appreechas to counceling is delineated in a paragraph entitled "counceling Toludques," theagh the manal recommends that the chaplain take an Interver: In Rogur's otepe in the counseling procese. The elient' expreselon, Insight, decision or cholee of goals, and his poufte mexiented action toward achleving the new goal and thet applteation to the thinking and wetlon of the prodigal son in the far country is conteldered 1110 hantigs.

\section{2pagard s. Arbuckle, Counealing: An Introduction.}



13 The Navy Chaplain, NavPers 10804. Washington, D.C. U.S. Government PFinting oftee. This publication is - manulil prepared for orientation of chaplains coning into the service. It contains 230 pages of which only 9 are concerned th the chaplain as a counselor. Chapter 1 , pp. 6-14. 
Nany chaplains will go alons with regers in giving enotions a place in "aetting" deciaion. In theee steps the client is trying to forge his emerging vilueideals and value-habits ipto a voriulng philosophy of Life, - and of religion.

In callng wth relfgious counseling, the publieation boxrow ereely from kll ther, May, and Joknoon. In this, one of the very fer offletal publicatione of the navy that deal wth the work of a chaplain, it could be gonorally atcted that it advises the chaplain to aseirilate Rogers, going on to add to thit process the influence of a raliglous atinistry which holds a higher standard of reference for atme, 1ceal. and Loyalties.

In owatng up the qualfteatione of a good eouneclor, The Navy Chaplain Liste many traits and qualleleations gleaned from fulther and Bogors. One brief paragraph in partlowlor Lo worth quoting as it follows the philosophical orlentation of this paper.

One of the chaplain's chlef tests a cormoler 1. that he make himself progressively unnecessary to the clients who seek his heip. His function is to promote growth. His attitude towands his work must be creative. It is not his role to be judguental. but to tee the client as an individual person, without being blind to his offense, feeling neither horwor nor curprise at any revelation or tatament. 15

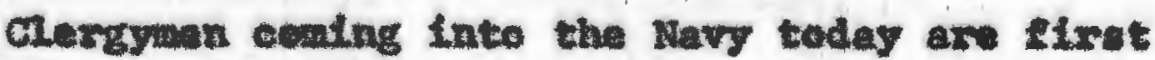
ondered to the Navy Choplain Sehool, offlelally decignated

$$
\begin{aligned}
& 14_{\text {Ibid. }} \text { p. } 13 . \\
& 15_{\text {Ibid., p. } 13 .}
\end{aligned}
$$


as roction: Indostrimation Diviaion, Guaplaine" of the United 3 States Naval Sahoole Omand, Nowport, Rhode Island. They attend the echool for a peried of six weele after which they are oxdered to attive duty. of this Indoctrination pertod, one tall ay is opent on the subject which is condueted as a cominar. Regulred rending for the seminar constats of: Rogere, Olent-tantered Therapy; Covanngh, Rundamental Pastoral Counsaling; and the eection on commuling in The Navy Ghaplais. The "Directive tor study of counguling," an octelal gulde for the preventation of this toplo indiented that the method ingloyed conelste of Lecture, group

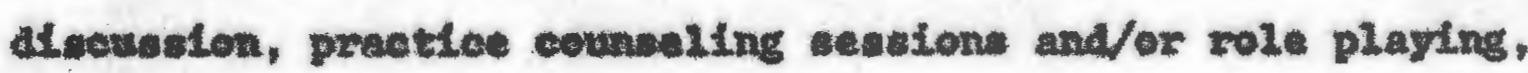
tollowed by a extleque.

It Io apparont that any intonsive training In coun- Lling by the novy ehaplain mat come before enterlng the service, or through poet-graciate "duty-under-Iastruetion," or on one' off-duty tint. Eneouraglng la the faet that theologieal acninaries of all faithe are recogntelng the


When it is recogalsed that of those adulta who sorght belp for enotional problewe in $1962,16 \mathrm{h2}$ per cent went to their elergyan, the importance of thi training 1. Ntal. "And so the elergyman has been eompliled by cirenntances to

16 According to a report conducted tor the Jolnt comwisaion on Nental IIIness and Health, set up by Congress in 1955. Quoted in: Elizabeth Ogg. Paychotherapy-A Helping Process, Public Affairs Pamplet No. 329, October, 1962, p. 2 . 
ascume the sole of the poor man's peyobothuraplat. ml7 Pre-

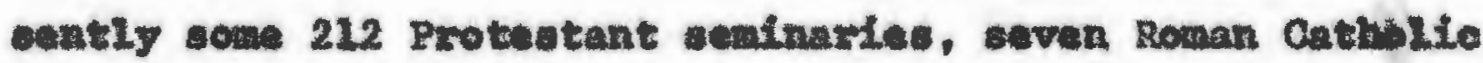
centers and three major Jewleh thwologieal cobools have prograns in elinteal partoral training, coumealing, or purelw Log. 28

One carnot tely in terns of the relationehip of coanaeling and the abaplatn whthout also condiarlng the relatenohip of covmeding and saligion. In a reeent book, Arbollt points ort som trafte often relatsd to raligion that he quations as part of a tharapoutic relationahip. Though be adnite that the bacie primalples of relfgton are parallelod in pogabology and poyebotherapy, he folls that "wome lndivicuale who are chlled elextyon, In the name of religion operate in ways which could hardly be eallad therapeute. 19

It If reognieed that there are poesibly alortywen whose practie of relf glon may kep then from entering Into a trate councling relationmhp, live the priegt and the Levite In the parable of the Good Samaritean, who paeced by on the other oide of hunen need becmuse thair nulfgton forbade them to touch a coxpee. There may be elexgynen who

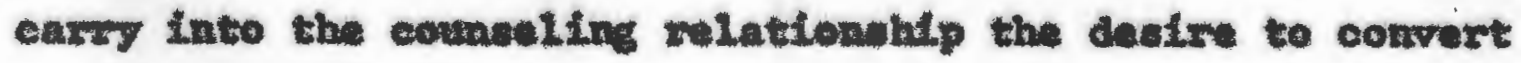

$$
\begin{aligned}
& 17 \text { Ibid. , p. } 23 . \\
& 18 \text { Ibed. , P. } 23 . \\
& { }^{19} \text { Arivekle, gr. eft., p. } 88 .
\end{aligned}
$$


or to pundeh or threaten. But these wotlons are not reatrieted to elergyon, but to any couneelor who lo rigld in his bellete or ropreanta atrong authorltarlen parwanioa. It It not so weah that becasue this counselor, whe happone to be a chaplain, wlll bring these undeelrable trait: Into the relationahip as it is how this comuclor, who is a ehaplafe, Fleve the nature of the counating relatiosuhip. When there is the attumpt to ohange or convert to values of the counastor and to be non-aceeptant of ollent vlewe, it cesses to be opunating relationehtp as hold in this paper. A chaplatin who has atefolent poytholegteal under-

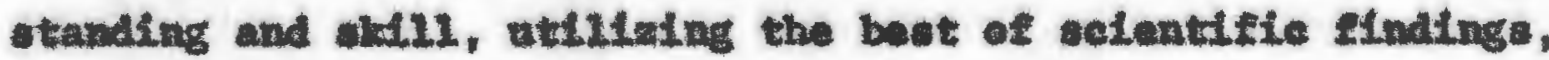
wh a truly wilgtoue coneept of the inherent value of the Individual, will be able to bu quite aceoptent of a ollent, whebever his adtration. Posalbly he will be more aceptant than Arbucial appears to be of the saliglowe couneclor who

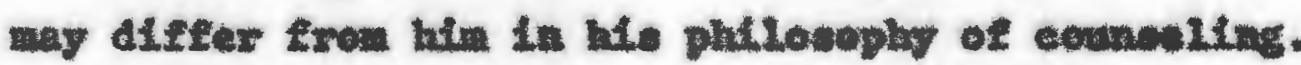

In contrast to the cifllien paetor whe ceraneals almost exelusively with hie parishionom (who axe asoumed to hold inilax religlous tenets), the navy chaplain mote negularly with thoes of many different religlove aftillations as well on those with none at all. In the Light of the sowemat fustified oxitict of a roligiow counselor who is unable to exeate a "pondientre zeletionship which alLowe the ollent to gaim an undarstending of himwelf to a dagree which allowe bin to take ponftive stepe in the light of bis 
new ortentation, ${ }^{20}$ the greution arlece: whet does a chap-





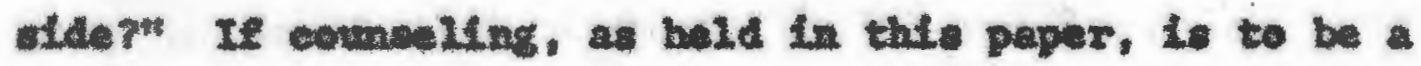



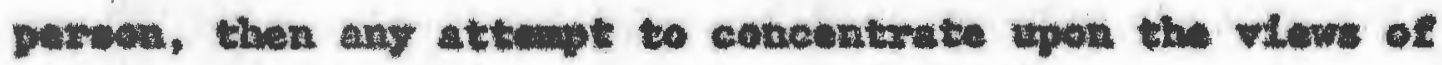
the chaplatin is wong because it dictracte from placing axelustre enplantis mpon the elteat.

Ving fecls etwongly that every pexeonallty problex

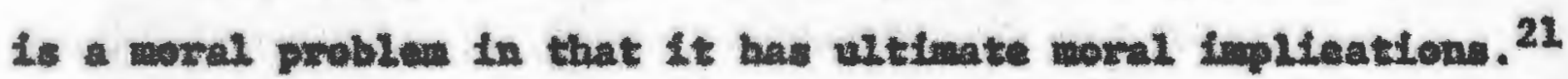
It wefers to the quector baele in all morale mew ohall Ine?"

The ond reselt of any succestul coungeling in a coxnect moral adjustuont to Lfe. The Insxperienced counoelor Io teupted to chort cute to this moral goal, and withest realintog it may pase on to the oltent a mpelete set of moral standarde. sweh a procodur short-etrates

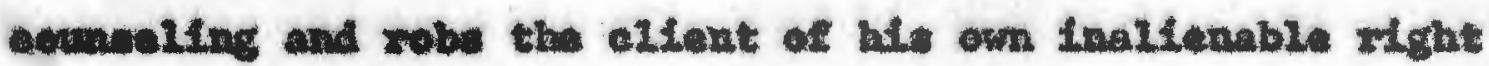

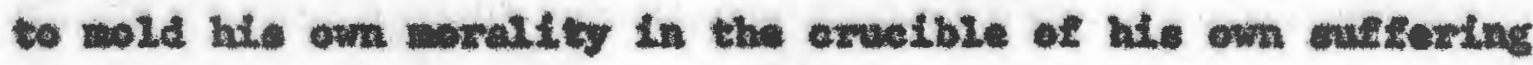
and tonolone.22 Bven if the vidwe of the connelier are Mght and the attenpt to indoetrinat is dons whout protest

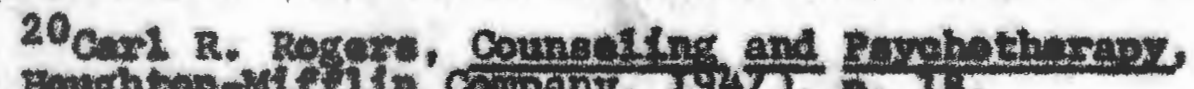

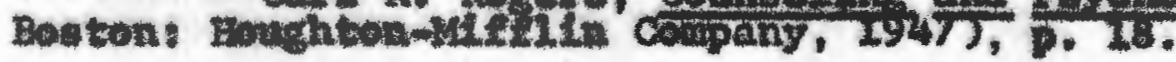

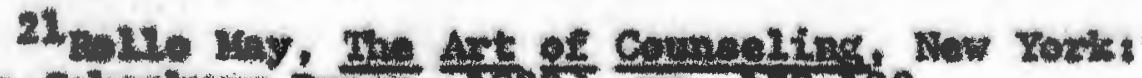

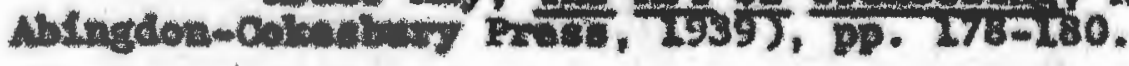

22xbet . p. 179. 
from the cleat, it is otII poos oomading becasse it Afverte from mat requires eoneentration in the reletionship. Deverthelese, elnce a chaplath abould not foree his Wlewe on the ollent of attampt to eouvert hin, neither ahould he 'depp-ofx' or discand his cenvietlon in combaling. In the Ifret ploce, it can't be done by a chaplata anywere then Lt can be done by any counselor. A couviction goes deep and is not a were opluton. To tumporaxtly diecard his convie.

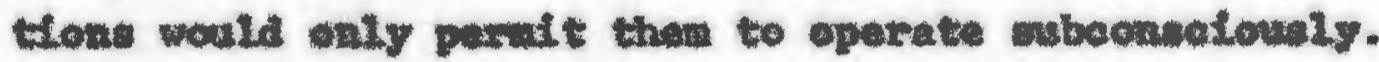

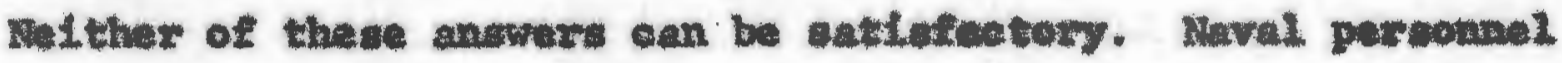
arpaet a ebaplain to buve sone cenvictions. Hoy axpect hin to believ in semething. A ollent may have an exroneous

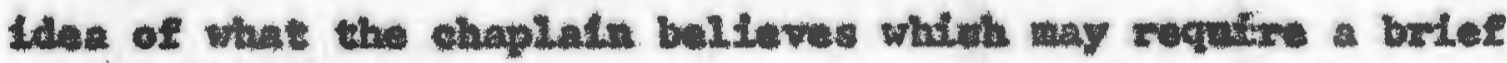
eormotive redefinition. Howevar, if a rogula exposition of

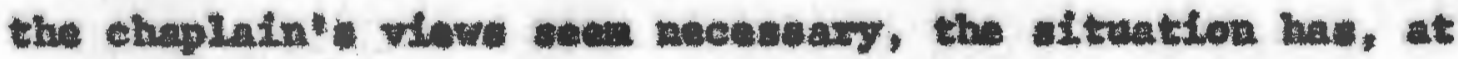
Least tuporarily, ceaped to be a conneling relatlonohip.

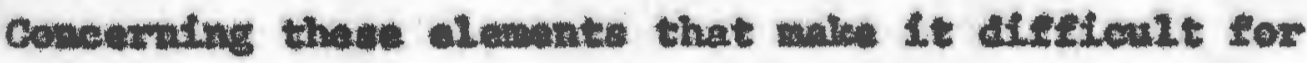
a chaplain to enter into the "molplng relationohip," Nay ctates the folloulag:

The only way out is the way of true religion, in which the coungelor learna to esteen and appreclate other persons without conderaning them. It is the way of underetanding, of "unprefudiced objectivity"; it is the way of empathy. The ability to "judge not" is the watershed between true religion and egocentric religiosity. It is supremely iliststrated when one who enunciated this comanduent tas hirself able to say, "neither do I ecadem thee." 23

$$
23 \text { wa. : } 176-77 \text {. }
$$


This inportant underntending of the dyamalen of Interperoonal selationuhpe was cogently atated in a publieathen dedieated to bridging the gap between religion and mdietne. In a sentence which appears at the top of an axtlele each month are the wordes nCouvereation which is



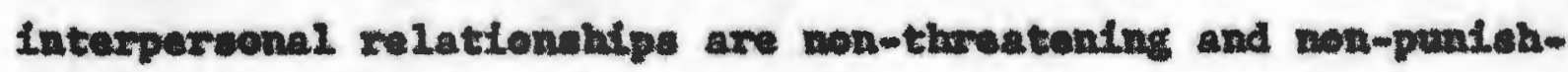
Ing we dovelop into Individuals that are cnotlonally secure, healthy, and excative.

A olguteleant wovenent in thle coutry hes been the energence of the Clinieal Pastor Training for protentent Ministere. It began in an organised and oyotenatie aense in 1925, when Anton Beleon, a Congragational minister, begen the praptice of tailng theological studente into mental bopltals Lor praetleal exparlenoe. A tow yeare later, under the encouragenont of Rlehard Cabot, a Boston phyolelan, there was organised the Councti for the Cllateal rraining of Theologieal sudente. From this grow the Paotoral Councaling movenent led by ouch was as Dicke, Hiltner, Oates, and Johnson.

One of the carly contributers to this wovenent was sullivan. Ele theory of Interpereonal relation ba been adopted by a number of rullgiowe counwelora. These writere expharte the Interpereonal relationohlp of couneelor and cornselee as affected by environiental factors. Fre, too,

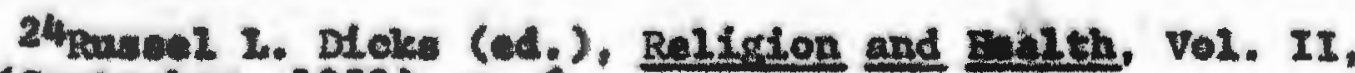
5. 8, (septenber, 1953), 1. 6. 
the I-Thou relationohip is stressed, the dynamics of "encounter," the meetling between man and man as well as between man and God.25 While in common with other procedures in counseling, varlous personality and peychological testa are used, this movement (ecsetimes called Reoponaive Counseling) rocognizes man as struggling for growth that is continuous in apite of apparent setbacks. As ouch, it views man in the context wth his fellowman in dialogue with himeelf, hie fellownen and his Greator. Because of thie, aid to the client may vary from mere clarification and reflection to ective encouragenunt of certain courses of action and to sustainIng the client so growth achieved may ba both perwanent and optinum. This while the directive counselor may conalder himeelf as vested with authority as a healer, and the "clientcentered" counsalor veete the ollent with authority to beal himeelf with belp, the "reoponelve" counselor veats anthority for healing in the creative boly spirit. 26

Thus the counvalor of this school ought to approach His task as one who is cownitted to the Chrlstian concept of agape, divine love, and as one who understands when people wis this bigh calling. By his own relationohip with God, he Le willing and desirous of halping his fellow man reach a full and abundant life hare as well as to aid hin in terms of goale, ideuls, objectives and purpoes for eternity.

\footnotetext{
25 Murtin Duber, I and Inou, trane, R. B. Seith (Nov

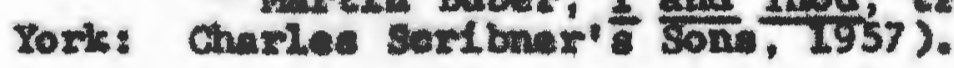
26 Penl Johnson, Parchologr of Pastoral Care (Naw York: Abligton Preas, 1955), P. /3.
} 
Frea Rank's theory of will runs an Important thread of the counseling fabrie in texwe of the cownoling relationonp.

It is he, ware than any other modern psychotherapist, wh he been able, without any depreciation of the strength of the obstacles and negative forces in the psyche, to assert the capacity of the parconality to talce indtlative in finding its om way if given half a chance. Rahk' theoretical wort may be considered to be the chief prerequisite for Corl R. Roger' athods in psychotherapy. 27

Deepus Inotght into this concopt of pureenality is expreseed by TIIIeh who hold that personality is that being which has power over Itecle-m power of buing, or action, ruaction and expression. W refere to its very nature which makes Lt what it is.

We call it "person" and attribute to it the capacity of becouing peraonality. onty on the basis of that kind of being which we acknowledge as a percon in ow social evaluations can personality develop. . It to a moral. concept, pointing to a being which we are admed to reopect as the bearer of a dignity equal to our orm and which we are not pernitted to. wat as a bagn for a purpose, becanse it is purpose in iteolf.26

The bacis of pareonality is in the individual buman belng, the person who alone anong all bings has the potantallty of celf-detexthation and, thercfore, of pursonallty.

Roters was the firet of the non-medical porohologiots to ehallenge effectivily the denination of the fleld of

27 waxd Blther, "The Poyohological underotanding of

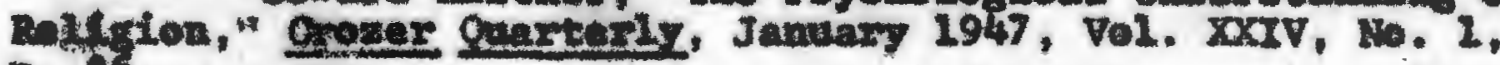
p. 26 .

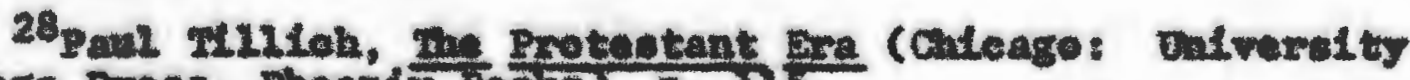
of Chleago Prese, Phoentr Bools), P. Lis. 
theraputute pogrehology by the malcal group. In the procese he bat to conetruct a poyohology of thorapy baeed on miniman cenativin in contrant to all previcue thoorice of therapy which

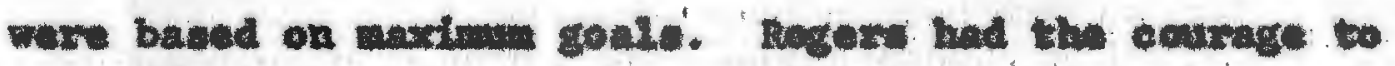

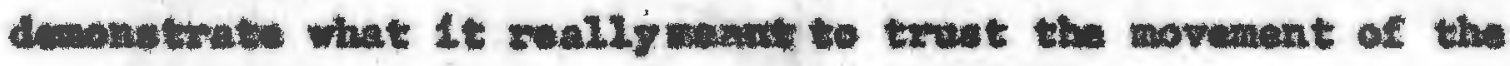

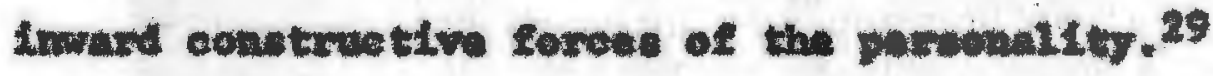

In a leeture givan at Oberitn College in the fall of 1954, Rogere has tormulated a broed hpothoule reganding the

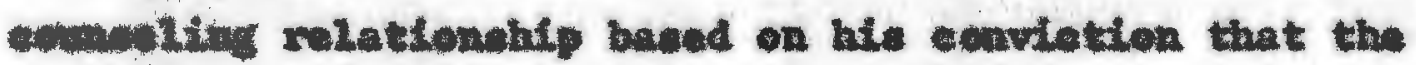
therapeutio relationshtp is only a spotal Inotance of inter-

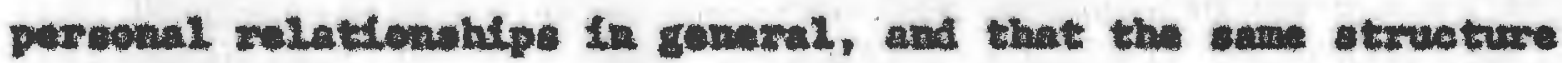

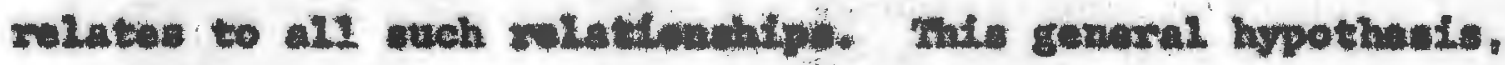

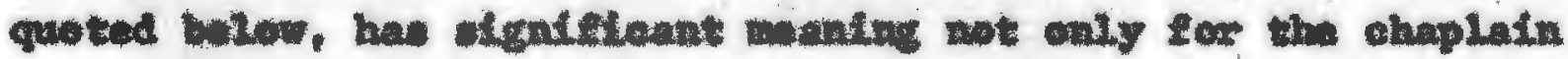

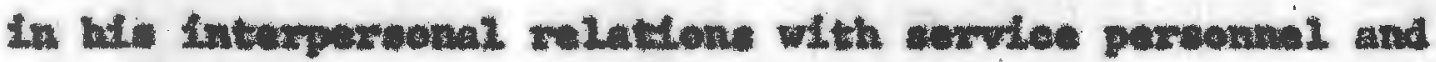

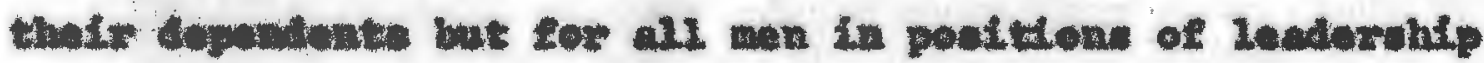

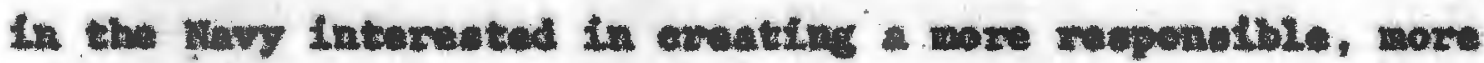
cooperatlve, now creattw organtatilom.

If I can exsate a relationahip characterized on ay part by a genutineneso and transpaxtacy, in which $I$ an my real feelings; by a wasm acceptance of and prizing of the other person as separate individual; by a sensitive ability to see hil world and himself as he sees then:

Then the other indridual in the relationship: will experience and understand appects of hinself which previously he he repressed; will find himself beconing better integrated, bore able to function eftectively: will become more sinfler to the person he would like to be; will be nore delf-directing and self-confident; will becoue more of a pergon, more unique and mone self-expreasive; will be wore understanding, wore

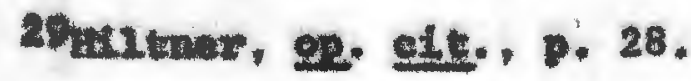


acceptant of othere: 112 be able to cope with the problew of life more adequately and wore ceatortably. 30

Reger'a bate Ldeas that the halping relationship is a proces of beconing, that the freeden and inner growth of the Individual ax of ultimate inportanes, and the fundamental asouption parvading bie work of the Algnity and fmportanoe of the buman bitug, bring hin elose to the exiotontialiet approach to eounceling.

The exiotential approach to pagehotheraps, which it present in mach of Boger's moltings, wales important contributons for the ehaplatn in his role as counselor. slgnifieant is 1te aceent on poyebothrapy as an underatandIng of what nakes man the manah being, and ite batic acoumption that it is poesible to have an vaderstanding of men which does not tragnantise his and dectroy hit bumanty as it etudies him. In weh a vast erganisetion as the revg, where it 10 easy for an Individual to becom owallowed up in a see of orfenimation end equipant, thie wedretanding of parsonality is neecseary for one to be of real holp.

The primary contributes of existential therapy io Ite undretanding of the Individual a bung,-not a state abject, but an exiating and changing being. "It is concerned wth ontology, the sefence of balng, and with Daceln, the oxistenes of thil partieular betng aftelng opponite the pegehotheraplet. $n^{31}$ Bavie to the exietentlal approach is

${ }^{30} \mathrm{Carl}$ R. Rogers, on Beoging a Bercon (Boston: Boughton Metin company, 2961), pp. Jums.


Ine., 2962), P. 37. 
Kiexlaggand'e penotzating analyals of anxtety, whloh is related to the question: how can one becone an Individual? Dequally important is his aoveept of truth a oubjectivity, trath as zoletionohp--the "partiefpant ebsurvation" of Sallivan.

A stady of the objectives of thls Buropean woveant w11 bear frutt for the couselor in exanining wil perception of sele.

One of the chief blocles te the understanding of human being. in hestern culture is precisely the over-eaphaeis on technigue, an over-eaphasis which goes along with the tendency to ase the human being a. on object to be calculated, managed, analyred. 32

of the vital Lplleatlon of this procedurs to the coumelor


between elient and counesior is a real, genuine one. "The

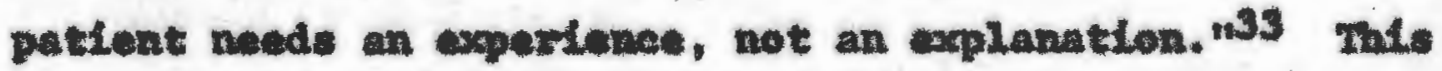

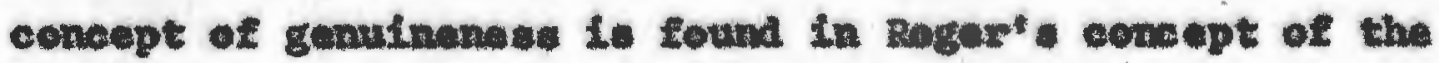
neture of the thaxapoutic nelationohlp. The tharaplat is coupared to the Secratie Mid-vite--ocupletaly real in meing thaxe," but baing there with the epeclele purpose of bolping the other person to bying to birth semething $\mathrm{Arom}$

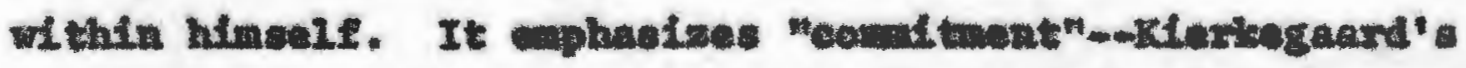
Lea thet truth exiets oals as the Individual prodvees it

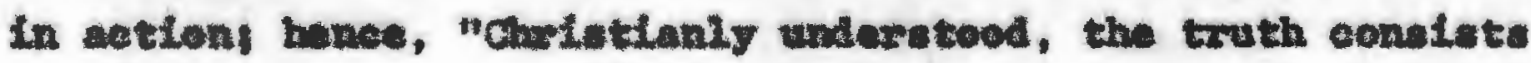

$$
\begin{aligned}
& 32 \mathrm{ma}, \mathrm{me} \cdot 76-77 \text {. }
\end{aligned}
$$

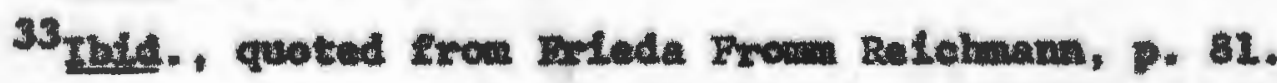


not in lawowing the truth bat in being the truth. $3^{34}$ These are polgnant ldeas and present a corrective in any collovaluation of the ehaplain's percoptien of comseling role. Here to a call for the ohaplain' to conolder his roponelbilities in the comeling relationahtp with ultimate concern, to dicecrs the procese of cownceling as a pareon-to-pereon envolvanant that operated on the Chriatian underetanding of love (agane) as Macteally not an enotional but an ontelogieal power, that it is the easence of Lfe Itaelf, nambly, the dymonde reanion of that which is soparated. 35

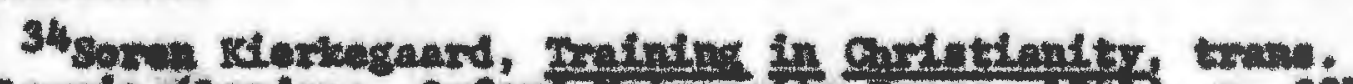

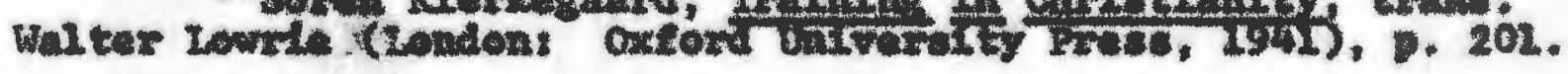
35tuleh, op. ett., p. xx. 
TAE MAVY GIENT

Frou the vast ooclologionl, geographtent area called Enerica, cone the wen and women who make up the prreonnel of the Nevy and their iepondante. And as the acrvicenan's

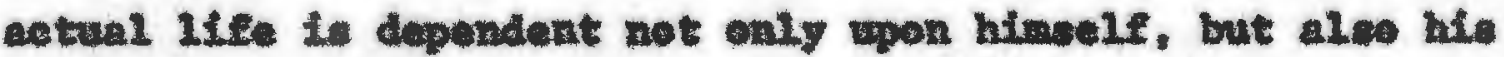

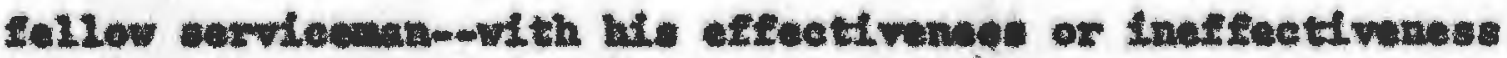
deterained largely by motration or lack of the ama--1t becones Ingerative tor the ohoplain to underatand and approetet the dramice of both the group and its component part, the Individuel. With awch mixed fonily balkgrounde, zaligione, cdneational Lvele, and varying aims of life by so many pereonme1, the kav I. faced with an ever present proble:.

Along with eoclal and racial atrtare, an Inexeaced popalation denefty has tended to aggravate the soelal elfmate In which wen and weaen--teanagers or college graduated-maxe eultured before they enter service. One of the unjor factors xuvelant to our econemic and coefal problens is the ohanges that have taken place in the howe brought about by the eoonomie Independence of woen, an Inoreaced divore rate, a decreace of parentel control, and lows of prectlge for the fondly as - social inotitution. This change has been reflected in a Lack of milgtow concern, a greater degendency upon material poosenclons and a sliding seale of values. On this polnt, 
J. Bdgar Hoover, in an article about juventle delinqueney, wrotes

I belleve that this menacing oloud, wushrooning ceress the nation with its terrifying portents for the future, Is indicative of a deep-seated national illness. I - cortaln that there is proof onee again you cannot dence without paying the piper. Over the past quarter of a century, all too many Americans have been Ignoring the basic traditions of work, discipline and vigilance on which our nation was founded.

We seen to have wieplaced the sense of valves which made this great nation. Self-induigence and the principle of pleasure before duty on a veet and gryting scale have becone a phenomenon of our adult world. 36

Before the covaneling tumation of the bavy ehaplatn can be fulfilled, there mast be an undarstanding of those who seck his help. What kind of valves its belind the behavior of the youth of this goneration?

Some light on this quention was given by allitary perconal during Character Education discusation claswes at the Maval Afr station, Quonset Point, Rhode Ieland, ettom

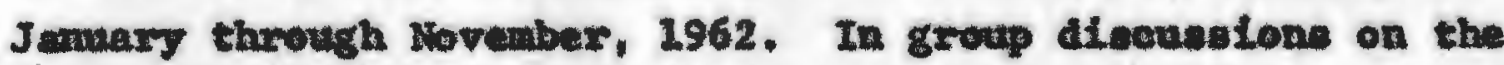
ubject of "volves, ${ }^{37}$ perconnal in twenty-2our different

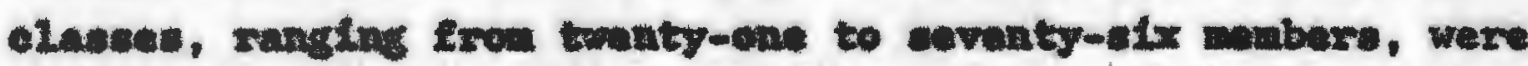
ankad what they felt sras most important to then in LIfo.

In thene groupe the avorage age was twenty, most of than graduates of high mohool (90\% male). Thels relfgious bacinground was mpresentative of meriea as was their geographicul origin. They were not aware that any opectal

36. Dagar hooves, "Counteratteck on Juvenile Delinqueney," inis bel, oetobex 26, 1958, p. 9 .

37 United States Navy and harine Corps Character cuidance Series II, Our Noral and Spiritreal Growth Here and Bow,

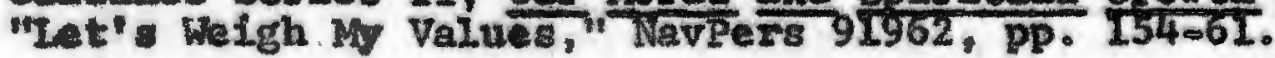


ctudy was belng made so thet they would not giv answers Wey thought wight be expected by the disenanten Leader. Thoy were asked to name anything thay cocimed, and they did,

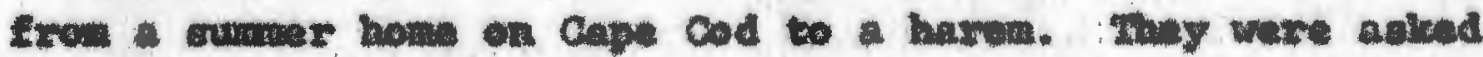

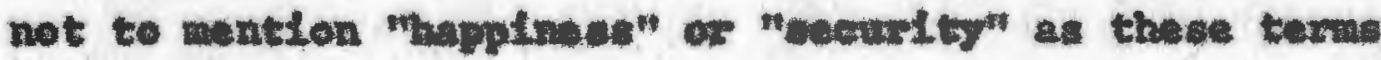
were too gonural and all inclwaive. When all itrens mantioned were Ifsted on a blackboard, the numbers of each elase wer. acked to choose the four ther consldered post raluable. A vote was taken by a show of hands.

It If reogefsed thet this was not a standardised


the methode weed. In East, the ldea of reoonding the data frca these wettings grov out of the interseting reculte of the discusetons and was not oxtginally planad. Fowever, it Is felt that this informal ourvy does give sone IndLation of the values of parapanal cexving in the Ravy today.


colected the Eollowing value as belug most important to then. Only values rweolving over flety vetes were recorded and in cach clase only thom valuse conshdered to be the cour most Important mere swpuestad. Table I chowa the remalte of thite Intertal curvey.

From the table, It can be oboerved that the fow most Important valwed chosen by allitary perwonel at quonset polat were: (1) Fandip and Fan, (2) Hadth, (3) Rolfigion, and (4) Finanefial seourt ty. 
TABLE I

VALUES MILITARY PERSONNEL AT QUONSET POINT CONSIDERED MOST IMPORTANT,

IN RAKK ORDER

\begin{tabular}{|c|c|}
\hline Valus & Mrabar Braferting \\
\hline 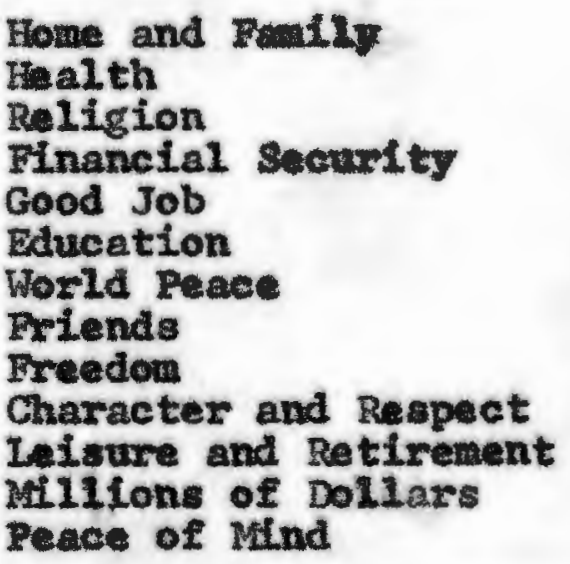 & $\begin{array}{l}865 \\
820 \\
607 \\
513 \\
257 \\
249 \\
232 \\
201 \\
156 \\
85 \\
76 \\
56 \\
55\end{array}$ \\
\hline
\end{tabular}

While there are many differences between navy persoancl and college students, due to the fundanental Eactors of the Navy, there are some almilartties. Mang of the wlltary pereonnel in this aurvey would be in eollege If thay were not fulfulling their alltary obligation and pragtleally all of than were about the same age as college

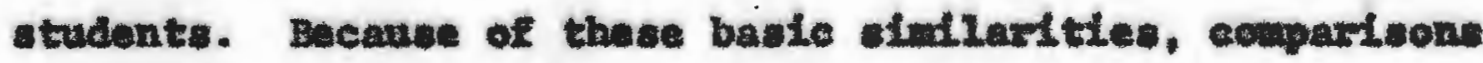
between the two group will be made here oecaclonally.

Jacob has written a book in which be analynes American oollege etudent attitudes and values as the rooult of varioes axveys. In one atudents were asked to choose from a lint of atx, the three thinge in Life theg thought would give the 
most satinfaction. The pareentoge of selectlons as ilrot, eceond of thind cholees, mads by 756 students is shown in mble II. 38

TABIE II

scancis of LEFE-SATISRACTON OF COLLERE STUDEMTS

Colleges Career Fanily Leisure Consunity National Religion

Barvand,

Radcliffe,

Mitant

83

93

60

20

17

19

In twath-Eoux classes at Quonect Polnt, a Enge and Fanily was wotrd one of the fous not liportant velues twenty-two thes and was tiod wites. Ind eompaxed quits

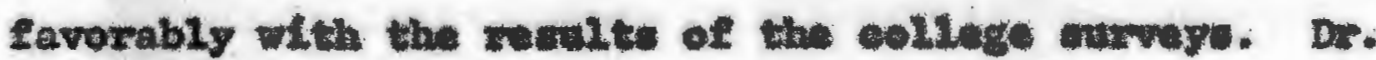
Jacob wota:

A happy fanily is a vital ingredient is the Aacrican student's seheme for a full 11fe. Seven out of ten expect their fanily reletionohips to provide then more atilifaction in life than any other activity. The proportion of wewen eondicy Ing maxriage and family of euprenge importance in thef. lives is even higher $(84 \%)$. 39

Whan wlitady pureonnol were anked bow thay wore po-

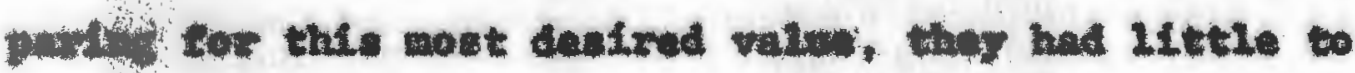

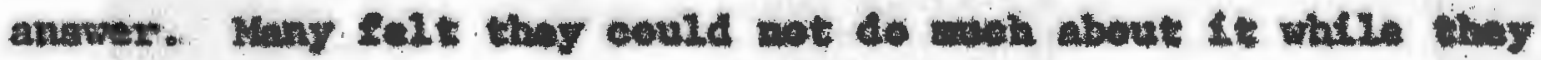

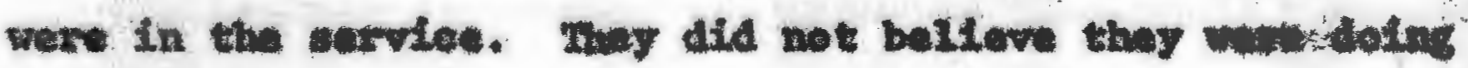

38 Philip E. Jacob, Ghangtro Values in Collere (N) Tusis: Harper and Brothere, 245\%), P. 16.

${ }^{39}$ Iute, p. 17. 
anything to hare their future fandy ef thar. The men were asised if they thought having caxual relations before marriage was harntul to their future taily happinese, and aost of thow said not. Thon vonereal disease, forced merrlages, gullt teollnge and payohological diffleulties were enggented, the wen secued to treat these matters 1 ghtly, an if thooe wore only cocasional conaqquences. One wast conelude on the becte of this that one of the value they vented most in life apparanty is not worth working for now! later, rea! the nen sald they wovld be faitherl to their wives and be good brebands whon they do get aaxiled, but many of then were not concerved now vith this.

Such moral laxity does ooncern the Mavg now. Dr. Jacob's studide ahow some college atudents share Ldea aind lar to those of allitary pareonal.

At cornell, in the valnee curvey, students by and large took no hard and fast tand on moral questions, eapecially in Judging the condect of others. They attached Iittle iaportance to chastity as a criterion for choosing a mate (less than $5 \%$ would break an engagement on the ground that the flance had premarital relations). . An analysis by the Soclal Seience Research Center concluded that about one-fourth of the students wer consistently permissive in their views, one in ten consistently restrictive and the rest in between. 40

Whon the moral sode is clexagarded and oweh action ceclally canetioned, it it Indleative that our whole woral cade may be changing.

$$
40_{\text {Inis., D. } 21 .}
$$


The cecond value anong the top Lour was Enalth. Pexhape President Konnody's phyaleal Altmese progran had

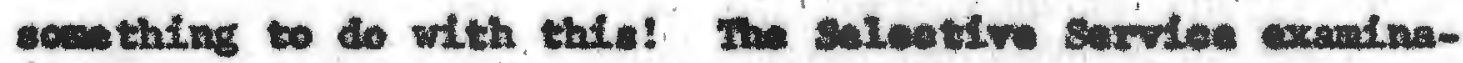
tione for World War II chowed that botween thirty and forty per cent of the men of the nation between twintsy-one and thirty-one years of age were unflt cor axay dates. 41 buring the war in Rorea the rejection rate (under Saloatwe servioe Aet) was thirty-eive por eent. 42

Commenting on the large pareentage of young men unfit Lor allitary service, Kajor General Frahey, foner Director of selective Sorvice atated "Into is indleative of a goveral phyeleal condtion of this countur' youth, of which we natconally chould be thoroughly achomad. "nts

of courbe the men in this aurveg were all in the wiltaxy, havine pasoed high phytionl otandarde, and were in goed balth. Nut, It was apparent in clase discuselon that they did not desire good hall th as natonal esat, but because good health would enable them to enjoy Iffe. There was no great enthaiben for conquering canoer or beart dicease for the betterment of mankind. What was inportant to each Indifldual was primarily his ow health and that of his fanliy. The majorlty of men took good health for granted.

\section{4lyese F. WhILane, Relthel Lfving (New York:} Mackllan Company, 1953), p. 4 .

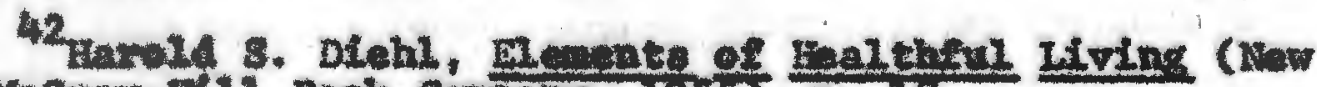


43 Ibtd. p. 11. 
The thind value antloned mogt frequenty of these Eour cholces wee paliglon. It was enoouraging to think that

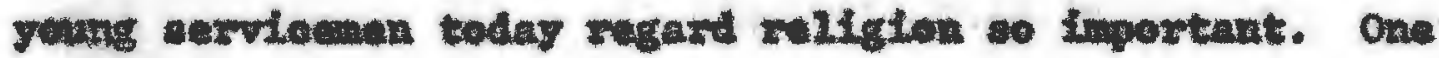
wght ouppose Rav ehopels wor ILlled ewary Sunday to over-2lowingt But Le It so?

In one clase of tuntry-two men, only one had been In chureh the purvious sunday. In another of twenty-olx,


valuable Is roligien to young wen in the Nury today, then? In wany of the clase dicesuatons non satd they belloved in religion and chureh, but didn't intend to do anything about It untsl 2ater. Balfiton had been a part of thoir life in the paot and they lenuw it was important, but appaxontly not Ingortant enough to do comething about it now.

Dr. Benoon Y. Inendis, Editor of the Yearbook of Ameriean Guxches and an expert on chureti statlotles for over lorky yeare, writing on the current seligieu mevival

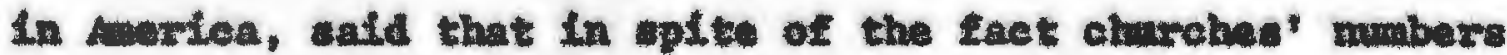
have tripled, "religion value have far lese impeot on Amertean 2ife today than they had in 1900. wh

On the subject of roligten, De. Jeepb wroter

The Cornell study fornd thet nost students attach great importance to a balle falt in man as good, and that this faith cuts across all opecific values. Their religious-ethical syaten $L_{s}$ an integral part of this faith.

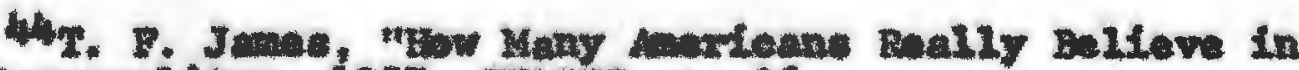
God?," Cotupgeltean, 1957, CxIII, p. 26.
} 
Yet their value-systens will wot stand up when undercut by forced ehoices butween alternatives which involve conflicting values. Nor does religion appoar to be a vital concern of woot atudents. 45

Sittler, in an addrese at the colden Amivereary of the Wht House Confexwee on Calldren and Youth (1961), 46 makes an extotonflal contribation on this polnt. He affirme the eact of the waning poner of the religlous tradition in

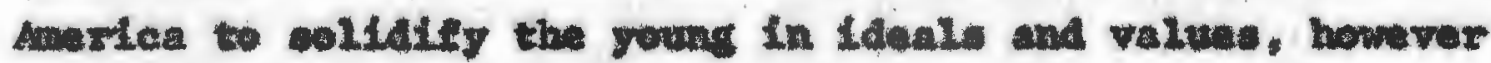
b widextrands this as a tribute to the young rather than a charge agelnot them. Syonting of the fact that many of no

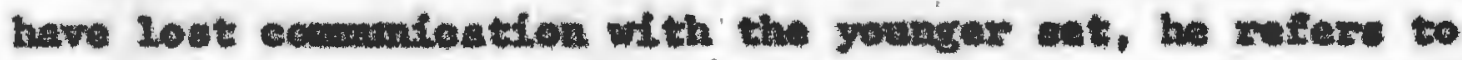


The Catcher In 늘 $\mathrm{Ex}$.

The lad revealed there is lonely, an outsider to the eulture which is his familial and school environment. His is saxtonio, not because he is tough but precisely because he is tender. He is not basically skeptical about elther the values of personal relations or of the reality of connitment to transpersonal purposes and powers. And he lo flip, contemptuous and bitter not because he despises values or ideals-o but because be sees these verbally celebrated by his elders, and regularly betrayed.

When, for Instance, the haro goes to Radio city Muste Fail during Chrietmas week, and beholds there a grave and aweoone moment of the religlous etory, the Pestival of the Incarnation, stripped, banalied and trivialized into an occasion for tinsel-prencing Rookettes, he utters an apparent blaspheray which is more reverent than the oweetly entraneed glee of the aduit generation there assembled. Fla judguent that "OL" Jesus would have puked!" does not revesl a opirit mavailable to an ideal and a value; it reveals precisely

$$
\begin{aligned}
& 45 \text { 1bis., p. } 19 . \\
& 46 \text { Joseph Sittler, "Interior Aspects of Change," }
\end{aligned}
$$

Values and Ideals of American Youth, ed. Bll cinsbers (New York and Iondon: Colvabia University Preas, 2961). 
the opposite--a kind of holy revalelon before a genaral phoniness that does not bat an ere in the presence of an abortion. 47

The remalning value of the top four eboeen through these discuestons wa Finanolal security. The men felt that financlal werrity want a confortable, secure Lring, but did not nocesearly mean having a cillion dollare. however, It It inturesting to note that in eive different elasese, a total of flety-alx mon did vote for millions of dollara as one of the four most tmportant things In 1ife. Mary believed they would antematteally have sinanclal securlty if they had a good job, bat thle may or way not be true. A good job was dafined in each clase as one that provlded perroval attufecton rather than great financial returns. In Jecob's studles anong college atudents, he found that only ten per cent of the studente in one curvey wanted a chance to carn a good deal of maney. 48

Near the botton of the liet of mot important value was Ireedow. Freedon Is one of Americe's wost cherfohed poseswatone and one would think it would rate high anong our valwes. several geare ago polls zoganding v. s. freodans were taken. Omsapoll abong high school benmageré sevealed that sixty per cent belleved the pollee and othar groupe should have power to ban or cewor certaln book or povtes. 49

$$
\begin{aligned}
& 47 \text { Ibld. P. } 294 . \\
& { }^{48} \mathrm{mit}, \mathrm{p}, 17 . \\
& \text { 49 h. E. Remaers and D. H. Radiex, "Thenage Attltudes," }
\end{aligned}
$$
Solentifle Anerican, 1958, cxoviri, p. 27. 
Twenty-flve par cent in the arvey belleved certain groupe ahould not be allowed to bold publis aeting even though they gathered peaeeably and only made speeches. 50

What do aflitary pereonnel think about freedon? It was not posulble to determatne how they would have voted on the queston above, bat in their Llet of valves, Exedon was mentioned frequantly but recelved only 139 votes out of 1,065 . The only reason given in class for auch an attitude whe thet they take freedow Eor granted. Clave monbers agreed unanimousIy that they would tight tor Anerican 1 berties if those Ifbertles were threatened by a zoreign power. And yot $1 t$ did not seen to cccur to the class thet we nay lose our freedom by our orn nogleet or Indifferonea.

It was also distabing thet world peace was mattoned anong the top four values only triee and tied a third time. The nen curveyed wore giving two, three or four years of their life to preecrve world peace and thereby maintain ouch values as a good howe and Lanily, and ruliglon. Int thls was not as Important to then as a good Job or edueation (according to the total number of vetes). When thic was brought to thair attention after the votes vere takan, they ucually caid that peace was important to then but there never had been world peace and they didn't expect that there would ever bu. Furtherwore, they said they had been asked whet they

$$
50_{\text {tbla, }}, 27 .
$$


wanted out of life, and therefore thay chose what would oult thas pareenally. This brings out on Important attitude of many modern American yoath.

Jacob was acked, "What do you think Le the nost

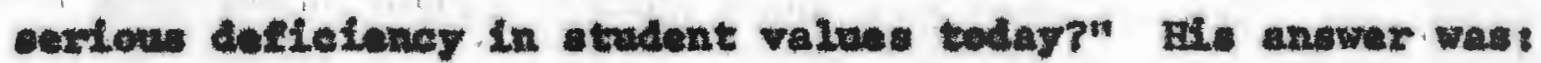

I think there are 'two' areas is which thare secm to be serious shortconings. On is in the extraexdinary interest of students in themelves rather than in the oomenunity around then. This wans that for the wost part, our present student generation is not prepared to support the things we have uvually considered of value In our eociety. . . Another deficiency closely related to the first is the students loss of a eense of Independence. They are meen too interested in belng "like everybody elee" to be olf-starters, and every society, to be a really dymanic and progreseive ome, I think, has to hove a leaderahip group with a high dogtes of ereativity and self-reliance. 51

Whyte, asthor of The Orsanization Man, cupports what Jacob stated about conforidty and serviee: "If they are going to be wortwhile, seniore want to be workwhile with other

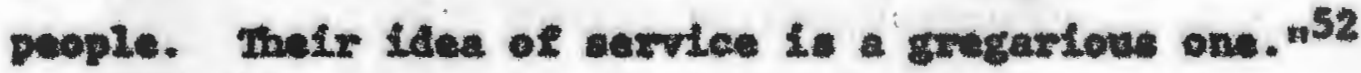

How ofallar college stadent and alltary parsonuil


for thougelves; religlen-mpinarily for thenselves; and Inonotal security--2or thamelves. And what de thay think of othexe? Caly niveteen out of 1,065 roted for a better world, defined as seelal ecridec, pablie eervice or helping othere. Whateen! Two and one-hale times as many voted for afllons of collaxe!


call, p. 35.

${ }^{52}$ Hula \#, Myte, Jx., The Corganization Men (Gardes Aty: Doubledity, 1956), p. 80."
} 
The question is, what does this survey on values anong military percennel show, if anything? Are cervicenen, too, prinarily interested in pleacure before duty, the constant search for the easy way? Do woral values play an important part in a consideration of the future life for young people?

Frow the tables in this paper, and as recult of personal discussion with the men involved in this curvey, it was found that young men in the Navy today know the good values In Iife and desire those values, but are doing little about developing thea or working for then now. But how can men expect to have values later without working for them now? In order to have a good home and family, one mut prepare now by learning the anthe of love, sex and fidelity. In order to have good health in the future, it is necesaary to talce proper care of ourgelve now and to compalgn agalnet all diseave. If we want rigion in our life we cannot fact pick it up" latar; we need to etart now. If we want a peaceful world in which to ratee our children, we wat accept national and International reoponalbilitien now.

And so there appears to be a Lallacy bere. The aurvey show that man want good values but do IIttle or" nothing ennetructively about tham. If these values are so important, men should act acoordingly, but genarally thay don't. Therefore, it it $\log$ leal to assume that the values really aren't as important to them as they say; at leat not now. 
The truth is that what a man values is one of the most powertul forces in deternining how he acts. The eurvey showed that among the perwonnel studied, their stated values were in sharp contrast to their actione, rather than in haxmony with then. This is a serlons problem for all facete of our cocisty. As educators, olergymen, counwelors, and parente, we must be wore concerned with what values we are teaching our youth by our action rather than by our words. For the prlorltes of the young follow the preatioe of the adult with absolute sertoances.

In our fact ohanglag world, the chureh, edwcation, and all aleaents concerned with tranmitting and faohioning the value structure of today' youth are not apared from the erosion that presently marice all valuo-carrying traditions. The threat of nuclear violence--a new violence--that promises total annihilation, Is a alnister pervading mood of the mind. The acoulturation of our contenporary soolety has been reflected In a deepenting evaluation of everything In term of practical service to the moment, education a career Iubrieation, and raligton as a moral ginmiok to protect us from a. strange 1deology. The ohallowness of our culture has embittered youth and has evoled woh an Institntion as "Mad" Magazine to expose the phouiness of our seclety. All of thece threats have contributed to the changing structure of Ideals and values In our gouth today. Our main concern is to try to underatand then in their exieting world so as to better enable us, in our 
Late Prealdent' cell "to do everything we can to plan ahead and to see that we prepare today's children well for tomorrow's worid."

The ancient words of st. Paul, In the Now Bnglloh tranalation, "Adapt youreelvee no longer to the pattern of this preeent world, but let your ulnde be remade and your whole nature thue tranoforwed" are poignantly pervaclve today and axe both good roliglon and trwe hmanica. They oxpoes the fallecy that a pereon can be parson in just any kind of world and also point out at whet level genuinely pereonal. Iife wet recoguie whet is right and devise ideale and values to advance it. The renaking of nind involves conclderably more from adalt inorlea that there is presently evidence to belleve she is efther sober anough to eee or distarbed enough to dealra. 
METEODOLOGY

After a reognition of the alde of his comaltments, and the dymanice of the couneding matonshtp, the Navy chaplain needs to evaluate his own ability and training for the task confronting him. Only through a process of selfexentnation w11 he be able to provide the meane for growth and maturity to those who come to hin for sounceling. In order to obtain some Ineight Into the pareeption Navy chaplains hold concerning their role as counselor, it was decided to formalate a survey quettonnais and oubait it to a repreeentative number of chaplatins on active duty. A total of 204 grestionnalres wexe mailed to a selected list of Chaplains, weing the "poster of Chaplain Corpe, USH-USUR, $1 \mathrm{July}$ 1963." It was decided to use as a population sample of the chaplains corps, the chaplain serving in the lst, $3 \mathrm{rd}, 4 \mathrm{th}, 5$ th and 6 th naval districts, which are locatedialong the east coast. This list of chaplains provided a heterogenoow group with a proportlonate varlety of geographieal representation as wall as religlow organisation and kavy rank. Thirty different church groups were repreented in the list of ohaplaine.

In order to recelve a high percentage of returne it was decided to make the survey brief, with several section composed of objective-type Iteme that would not take too long 
to complete. Responses that would refleet practle rather than theory was preferred, as practies does not alwaye contorn to theoretical orientation.

The flret part consisted of twelve itens to which responses would Indleate trends toward directive or clientcentered procedures. The elrst alx itens were concerned with six Eactor of councoling teohnique with the next aix items repeating these Eectors in onder. Chaplains were requested to respond to these Items by Indieating whether they atrongly agreed, alldly agreed, were undecided, Allly dieagreed, atrongly disagreed. From the iten responses to these five categorles two rating veales were developed--a Directive Score and a congruence seore. The Direotive score was based on welghts of one to five anolgned the five eategorles for each of the twelwe itess with poseible scores ranging fron 12 to 60 . A high pirective seore would Indlcete authoritarian-directive procedures. Congraence score was based on consioteney of response to the paired items representing different factors with waighta of 0 to 4 aseigned. A range of 0 to 24 was posuble for a Congrwence Soom, a low score indieating more oonaloteney.

Other itcons in the queationnalre concerned frequency and types of probleas constituting the bhaplains counealing load, acadende or clinded trataing in councoling, the percentages of counselees returning for extended combeling meacions and Latty, a briet statenent of to the nature of the 
counseling relationohip. A copy of the ourvey questionnafre 1. found in Appendix (A).

After a revised form of the ourvey quattlonnalse had been completed and approved by the major protecoer at the Oniverafty of Rhode Island, it was protented on fifteen graduate tudente enrolled in the counselor edveation progran at that unfverelty. Tro leading councelor-edveatore mero alse asked to react to the questonalre to halp deterwine its edequacy. The counselor-educatore received a Drective Score of 26 and a congruence scere of 3 , sweomanding a $\mathrm{Lew}$ winor changes in the wording. The graduate otudente came up with an average Directive score of 25.72 and congruence seore of 7.14. The arrvey queitlonnaire was also adninletered to 16 elergymen of the Naval Reserv, who were attonding a SandeIv1ty Seninar at the Navy Chaplains School, Hewport, Phode Ieland. This group, though never having served on active duty obtalned an average Dimettve seore of 32.9 and a Congruenee Secre of 10.8 .

The above resulte appeared to Indicate that the questonualre was fairly coneletent and after a few winor ohanges in the wording In Itan (a), (e) and (e) of the firet section it was printed and prepared for distalbution. Pexulation was sought from the Complatne Divialon, Bureau of Daval Pereonne1, Waihington, D. C. to make thie otudy. Thil was felt expoditlows as the author is on full time astive duty and alco because the ravelto of thile 
quetionnaire mag have sose value to the Chaplains Division In Its adainiotration and future planning of counselor tralning. In reply, the pirector of the Chaplains Division atsed that:

Since this is a private survey undertaken for your personal development and education, it would not be appropriate for the Chief of Chaplains to either ive or refuse such perraision. We comnend you for your efforts, particulariy since they will certainis better equip you professionally to fulfill your ministry as chaplain. ..

A covering letter was then composed and duplieated and the curvey questlonnaire of th Its letter of explanation was mailed to the 204 ehaplatns selocted for the arvey. A copy of the forwarding letter appears In Appendix (B).

Those selected for partholpation in this atudy vere for the most part serving on Xavy and Maxine Corps stations on the ceot coat, or on boand shp In the Atlantle Fleet. Five ware eent to Great Laked, ILInols, and four to San Diego, California and one to Rota, Spatn, to give an equitable dietribution by milgious aftiliation.

The tabulation below indicates the number of quevtionnuires distributed by rank as well as the number in each rank componing the Chaplain Corps as of $1 \mathrm{July} 1963$.

\section{TABLE III}

NUMRER OF QUESTIONWAIRES SEMT SHOWTHG DISTRIBUTION BY MAVY RANK AKD 20TN, NONBER IN EACH RANK OR CHAPLAIN CORPS

\begin{tabular}{|c|c|c|c|c|c|c|}
\hline & CAPT & CDR & $\begin{array}{l}\text { Rank } \\
\text { LCDR }\end{array}$ & LT & LTJG & TOTAL \\
\hline Questionnaires sent & 21 & 40 & 98 & 48 & 0 & 204 \\
\hline Inober in Corres & 64 & $\mathbf{1 5 7}$ & 352 & 328 & 21 & 912 \\
\hline
\end{tabular}


50

Questionnaires were not sent to the twenty-one Lieutenants (Junior grade) for they were either still in Chaplains school or had not yet received a permanent duty station. In either case their time in the service was only a matter of weak s or months. 


\section{PRESENTATION OF DATA}

A total of one hundred and seventy-two chaplain reeponded to the eurvey quantelonnaire of a total of two handred and four eent. This represents a response of approximatily 84 per cent which 10 felt to be extromely high for this type of questlonnalre. Part one of the quetionnalre asked for a reaction to wrelve etatemente ropmeenting olx Lactere relovant to the dyamies of commeling proecdure, which are treated balow. A complete tabulation of the total reponees to this cection appoar In Appendix (c) Indieating how the chaplaine responded to cach 1 bew. Uetag a soorting lag daveloped fren the vating seales, a Directive seore and a Congrushes score was computed for each cheplatn answering this ection. Each of the twelve Itens affered Itwe poedible reoponses wh woighte from one to flve asplgad. Iters $(a, 8),(0,1)$, and $(e, k)$ were directive atatemente and were ansigned wolght: in inverse orver.

of the total nuber of chaplating anwaring this section the Directive Seores ranged frow 17 to 46 wth a wean of 31.09 and a standard doviation of 5.91. Cverall Congruence Scores abowd a range from 3 to 20 wh a mean of 20.64 and a etondard doviation of 2.28 .

Fron these figume It appears that the chaplaine as a group tended to be a little more client-aentered than the 
sxteen clergymen at Newport, but more directive and authorttarien in their procedures than the groduate students reported above.

A careful analyels of these resulte, whan broken down Into navg ranks, Indleat a trend toward increasing authowcarian-diretiv methods in the lower ranks. Table IV Lists the total scores for the four navg ranks repreaented in this survey.

\section{TABLE IV}

MEAN, RAMEE AND TOTAL OF DIRECIIVE AND CONGRUENCE SCORES OF CHAPLAINS TABULATED BY MAVY RANK

\begin{tabular}{|c|c|c|c|c|c|}
\hline $\begin{array}{l}\text { No. of Chaplatus } \\
\text { Mave Rank }\end{array}$ & $\frac{18}{a p t}$ & $\begin{array}{c}38 \\
\mathrm{cBR}\end{array}$ & $\begin{array}{c}62 \\
200 R\end{array}$ & $\begin{array}{l}\mathbf{S 2} \\
\mathbf{L 2}\end{array}$ & 170 \\
\hline $\begin{array}{l}\text { Direotive Score } \\
\text { Mean } \\
\text { Range }\end{array}$ & $\begin{array}{l}524 \\
28.55 \\
21\end{array}$ & $\begin{array}{l}1,158 \\
30.48 \\
17\end{array}$ & $\begin{array}{l}1,942 \\
\frac{31}{27}\end{array} .30$ & $\begin{array}{c}1,811 \\
\frac{34}{26}\end{array}$ & \\
\hline $\begin{array}{l}\text { Congrumee Score } \\
\text { Mont } \\
\text { Range }\end{array}$ & $\begin{array}{l}175 \\
20\end{array}$ & $\begin{array}{l}10.63 \\
15\end{array}$ & $\begin{array}{l}598 \\
\frac{9}{15} .64\end{array}$ & $\begin{array}{l}569 \\
10.94 \\
22\end{array}$ & \\
\hline
\end{tabular}

Directive score renges from 12 to 60 with high score indicating tendener, toward directiveness in counseling technigue. Congruence ecore ranges from 0 to 24 with high seore indicating inconsiateney in anowrs. Of the chaplains responding, only two left this. first section unanswered.

It io Intereating to note that the elghteen captaine scored the lowest average directive score, mean and rangé ouggests that they as a group are more ellent-centered in their cotaneling procedures than the other three ranks Listad. They 
alto had the second lowest congruence score dignifying wore coneloteney in thelr anwwers. This could poatbly be due to their greater exparience in the eervice, their age, and higher level of training. The Captains averaged 21.5 yeara of active duty in the Navy.

to determine if the chaplating of different church affllations would divolose ang trende towerd differences in councaling procedures, a coptlation of their responees is given below. Only the four religious groups having the Largent number of ropresentative roplying are tabulated as the other elaureh bodies did not have enough reeponsea to reveal ang algulfeant differenees. A table of all returns by ralgtous groups is Lound in Append $\mathrm{x}$ (D). Chaplain from tour relfgions organiantions reacted to the curvey questionatre as shown in rable $v$.

TABIE V

MEAN, RATEE AND TOTAI OF DIRECTVE AND CONGRUENCE SCORES OF CRAPUATRS OR FOUR DIFFERENT CHURGHES

\begin{tabular}{|c|c|c|c|c|c|c|c|}
\hline Mo. & Chureh & $\begin{array}{l}\text { Direc- } \\
\text { tive } \\
\text { Scote }\end{array}$ & Mean & Range & $\begin{array}{l}\text { Congru- } \\
\text { ence } \\
\text { Seore }\end{array}$ & Mean & Renge \\
\hline $\begin{array}{l}25 \\
24 \\
21 \\
10\end{array}$ & $\begin{array}{l}\text { Roman Catholic } \\
\text { liethodist } \\
\text { Presbyterian } \\
\text { So. Baptist }\end{array}$ & $\begin{array}{l}886 \\
805 \\
684 \\
589\end{array}$ & $\begin{array}{l}35.44 \\
33.58 \\
32.52 \\
31.00\end{array}$ & $\begin{array}{l}17 \\
18 \\
11 \\
19\end{array}$ & $\begin{array}{l}307 \\
271 \\
204 \\
119\end{array}$ & $\begin{array}{r}12.28 \\
21.39 \\
9.71 \\
10.05\end{array}$ & $\begin{array}{l}13 \\
13 \\
15 \\
19\end{array}$ \\
\hline
\end{tabular}

Frow the above Elguren, the Rean Catholit chaplatns seen to be the wost dirvative-ortented coungelore of the 
group, yet their eongraence score indieate that thay were also more inconsiatent in their reeponses than the others. The Probyttarlan chaplains showed the wost conclotency in their anowere to the gueatlomalre while the Southem Baptiat chaplaine came up with the lowed average directive score of the dffearant chareh groups as well as the over-all group of 172 chaplains. The reaults were sowewhat auprideing, for pulor to the ourvey it was expected that the Boman Catholio cheplatwo would indicate a uneh higher direetive score due to the authoritarian nature of their cecleslastieal oxganisatica. Aleo, it was not antelpated that the Baptet group would be the moet ellent-centered of the four lieted as they are conmonly felt to be more parochlal in thetr viewa than the Prevbyterian or Mathodists.

In a careful stridy of the resulte of the twelve Items anployed in the flret section of the questlonnairs, sane Intereating material is presented. Iteas (a) and (g) were eseigned to indieate councelor bellef in the capaelty of the individual to develop and grow. The chart In Appondix (c) show that of the 170 chaplatine answexing Iten (a), only 18 per eent felt that some individuals who cone to then for comecling are capable of ettablinhing approprinte goals and values. If this La a valid indiostion of the chaplain corps as a whele, It reveals a rather unoptemietie view of man. Iten (\&) was also concerned wh ellent competeney, but was stated in a pouttive manner. Of the 162 chaplains reacting 
to this iten 89 per cent agreed that pereon can develop in a benefleial Alrection under favorable conditione. A very high pereantage of chaplaine were inconeletent in their anowere to these itume. Ifther the atatenents wexe not clear17 worded and were mieunderatood, or else 138 chaplatns reacted realletically to Item (a) and gave "Lip-eervice" to whet thay afght be expectud to believe stated in'iten $(8)$. Inamush as these itans ware pretested with oounaelor educators and graduate ctudents in this field and was not so inoonslatenty anowned, the latter lo nore probeble.

Iton (b) and (b) denlt with directive councelor techatques and in anowerisg both itams epproxinately one-third of the chaplatus reeponding disegned that the councelor should solve the probleas of the ellent for him. It was noted, howewar, that the Ifeutenante were equaliy divided on thle Iton while the othor three ravks in an aceending ecele had a highar degree of elient-eenteredness in the ir reopones. The expaneston of atisapproval by a counselor of imerral acte revealed by a clent is the concern of iten (c). Agreesent of this atatament was shown by 43 ehaplatna, 12 were uneertaln, while 203 chaplains felt that this was not a good counseling procedure. Roganding this Lten, one eaptain wrote on his quetionnaire. "otwong if diagrwe is the anower for counsoling technlgue, bat when does a religlous counselor indleate to a ellent disapproval of imorality?" $(1)^{53}$ Iten (1), which was also oonoexned whl judgont of client quaptomatres which are identified by that maber. 
behavior by counselor's own syuten of values showed reeponses congletent with Item (c), in that a large enjortty of chaplaine felt that this wa not a good couneling practlee.

Rolating to counalor ecceptance and understanding of a ollent in the counseling soselon, Iten (d) stated "I counselor should sccept what a olient sags at face value." of the 171 chaplaine answering this 1tew, 40 agread and 126 expresed disagrement. Iten (j), "The stated problem of a elient is not alwaye the seal difficulty" was almost unanimounty accepted by 268 of the 170 chaplatne. Inate reaponses ind Icate an inconcletency as both of the above itens were non-directive statements, for of the 126 dieagrealng with the firet Itea, all but two of thase agreed with the latter.

The importance of reacting to the feeling of what a client expresses rather than the intellectual content is the Locus of Item (e)! "A commelor shovid concentrate pore on what is being sald rather than why it is said or how it 10 apreseed." of the 168 chaplains reacting to thl otatement, 133 disagreed, with only 29 disegreeing and six ware undecided. This iten was paired with (k) conoeming couneelor expereston of interpretations or seelings to a ollent. This atatement holds that wore exphate should be pleced upon the teelings of the client and that the comeetor should not impoes his Interpretatione or feelinge Into the relationahtp. Stxty-two disagreed with this 1ten while 98 agreed with ten undecided. 
The techique of expportive counveling is a factor in 1tema (L) and (1). Though there may be some therapeutic value in this techalque, generally counoclor approval gives 2al oupport and Leads to cllent dependence upon the counselor. Dopenses to both of these 1 tans indicate that a majority of chaplatns reponding belleved that a goal in counseling ahould be to give support to the dilent and male the client happs.

The second part of the questonnalre adked for an indieation of the nature of coungeling problene enceruntered by navy chaplatns. . They were asted to Indicate in the colvuans on the right of ten types of problem areas, whether these cases were experlene "irequently, "often," "eeldom," or "haver." Cuaplata are reguirud to make quarterly ataris-

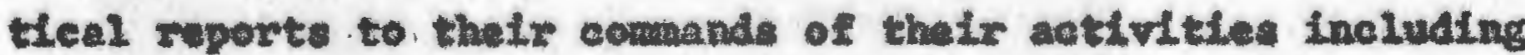
comnealing cases. Mast ceclestastieal codorelng agenoles also reguire a monthy ruport of pactoral activitios, but nefther of these ruports are coneerned with the types of combeling cages neported. Reognifing that the reeponses to this question are from menory to gome extent, the reaulte may not be highly eccurate but they do indleate a Laxgie vartety of problem areas eneorntered as well es which problens chaplains feal cone to them noet often.

Frou the table below, it is evident that "waxital diffleuttes" seemed to be the most frequent counseling problea coning to the chaplain, and "edueational" or veeational 
The post-graducte training referred to hore Indicates full tine training for a year at one of several untveraities or the Neminger Inotitute, oltielally raferred to as "duty under Inotruetion." The other course work for the wost part, wae taken by chaplaine during ofe-duty tima. These anowere reveal that 72 of the 173 chaplaine seeponding did not have any farther training in eownaling ofnes leaving ecinary. Yot, of this total group: 13 received a years post-graduate Instrwetion throagh the Navy progran, 10 posecesed advanced degreas, 8 had particlpated in elinical training, and 69 had talen courees at graduate ochoole durfing oft-duty hours.

A liating of thees resulte appear in Table VI, frivg the number of chaplatws, by rank, recolving this tratining.

TABLE VII

GRADUATE LEVEL TRATING IN COUNSEING AND RELATED FIBLDS REPORTED BT CEAPLAINS

\begin{tabular}{|c|c|c|c|c|c|}
\hline molnter & CAPT & oDR & LOMR & $\mathbf{2 5}$ & ropas. \\
\hline $\begin{array}{l}\text { None since sealnaxy } \\
\text { In-service post-graduate school } \\
\text { Advanced degrees } \\
\text { Over } 6 \text { graduate courves } \\
\text { Under } 6 \text { graduate couraes } \\
\text { ainical training }\end{array}$ & $\begin{array}{l}4 \\
4 \\
1 \\
5 \\
5\end{array}$ & $\begin{array}{r}14 \\
2 \\
2 \\
13 \\
6 \\
2\end{array}$ & $\begin{array}{r}29 \\
6 \\
4 \\
4 \\
3\end{array}$ & $\begin{array}{r}25 \\
1 \\
3 \\
14 \\
3 \\
3\end{array}$ & $\begin{array}{r}72 \\
13 \\
10 \\
51 \\
18 \\
8\end{array}$ \\
\hline Total & 19 & 38 & 66 & 49 & 222 \\
\hline
\end{tabular}

Poselble explanation for the fact that 41 pex cent of this group had no opportunity for further tralning could be 
ather Indifterence to opportanat ty or Lack of opportunity due to duty aselgnicuts. Another factor capable of affecting the opporthmity to take part in awoh aetivitles in the attitude of beth the tnadiate conaand and the cuparvieory chaplain. Iack of apprestation of the importanoe of traiafing in counceling by elther of these would tend to diweourage participation. Eowever, in the last fed yeara, thare has been Inereaning enoeuragenent for ective duty cheplains to avall themelves of nary-oponoored catnare. Also more appropriated funds are being alloted each year for the post-graduate training pregrem.

sections (4) and (5) of the guevtlonnatre ruquested

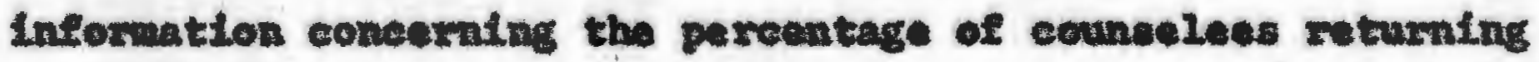
for two or more oevnoellag cesclone. In evaluating these responce, it was felt that the reoulte on this part of the curvey were co seattered and incencluaiv that they lecked manting and ahould sot be included as a part of this study. The manner in which the navy ehaplain views his role as a counselor concerne the last wection of the curvey quostomaim. Each chaplatn was abled to define briofiy what be bilieved eovaculing to be. Out of the 172 ehoplatns anowering this ourvey, 19 Left thio eacton blaik. The

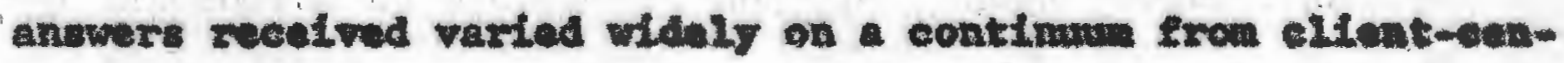
terednes to authorltarian-directive methods. A caraful analyeis of these defintitione revealed that thay could be catagorised by cartaln Iactore ilated in Table VII, with 
those at the top of the lict tending to be authoritariandirective and those at the bottan more alfent-eentared.

TABLE VIII

SUMARX OF DEFINITIONS OF COUNSEIIK GIVRA BY CHAPLAIMS, DI RATR, RANETHO FROA DIRECTIVE 20 HO4-DRRECHV

\begin{tabular}{|c|c|}
\hline type of Batinteion & Rubu of Gaplates \\
\hline 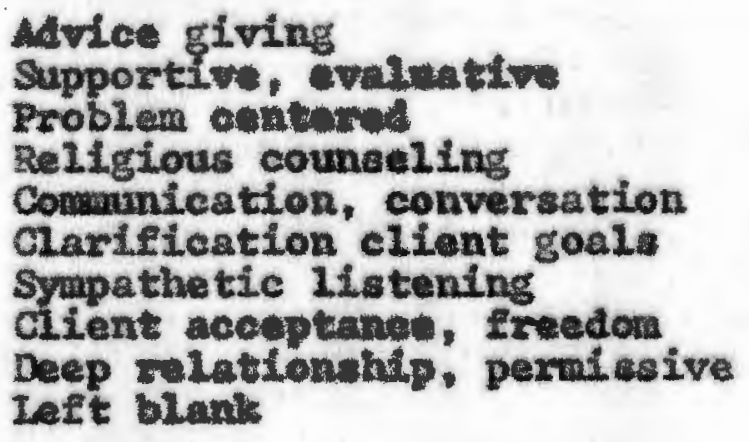 & $\begin{array}{l}22 \\
26 \\
21 \\
10 \\
15 \\
21 \\
14 \\
9 \\
23 \\
14\end{array}$ \\
\hline Total & 172 \\
\hline
\end{tabular}

One ohaplain, whe had left the entire quostionnaix unanwwered, wrote acroas the top of the tormet Martlelpat. motly in 'directive comneling' as Cetholle poleut. 'Misnte' come to we because they are sedking alreoture cormseling," (173) Another chaplati who hed recelved the Navy pout-graduate

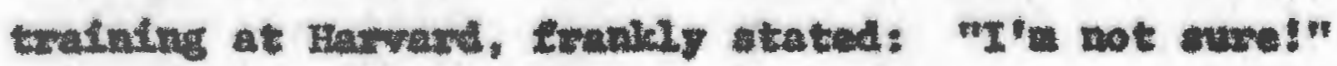
Gonvrally, the responset varlod counterably as observed in rable vit.

of the Afgtwen Ceptains anwering this cecton,

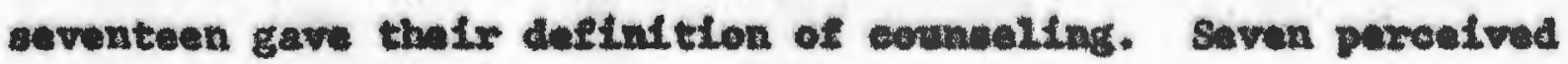

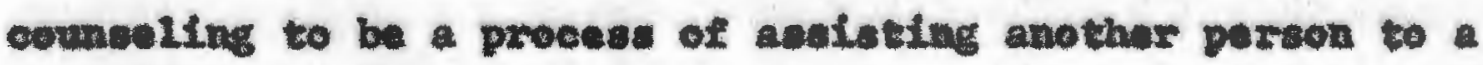
colution of a problem and ectabliohant of worthulle goule 
and valups. Three atresed the importanes of the atmosphere or melatountp created where a client can feel free to axemine hle own valwes, to gain tnolght to reach a satis-

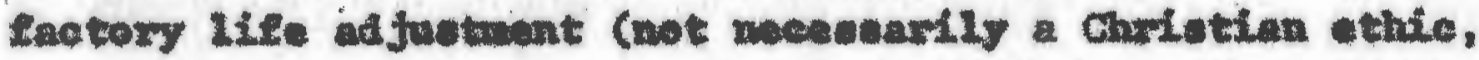
ono chapiatu addad (2)). Another deflned cotmading as a procese, "wy which the resources of an objectro wind io uncmotelonally related to thuspurash and pubblen of another persou" (3). Anothex felt that it 15, "bo asolst a person in

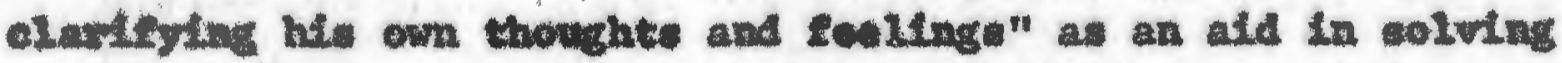
hi. problin (5). One ohaplath drove a I1Etle deper with hlo pereeption of ceanueling as e rprivilege of belping the counselee confront himedf that he may aceoptably contront othere. . " (9).

The importance of mietening" in the relathonshp was polntad out in another (21) whlch is probably a needed reninear to many chaplatne. Som good advice was given as to operathonal wetbod in the collowing remponpe:

The chaplain does not cocree, woralize, push, divert or Arvet. Instead b attenpts to lead out or draw out resources and atrengths which can boose operative only as they are helped to well up with in the parishoner. (15)

The thirty-efot Commanders who seturmed the questolnaire all contribnted to thi last nection. Six dealt wth helpling the counselet usderstand the nature of his problem, and of $x$, with atding person to an understanding of ouf. Five constiexed coanaeline as a mans of belping a person help hisself in moeting or adjucting to life, and Ifve streacd 
the inportance of the inter-perwonal relationohip created In whtoh Invight, growth and IIte-enaning are eought. Maaponses varled from "tho abllity of the counoclor to make the

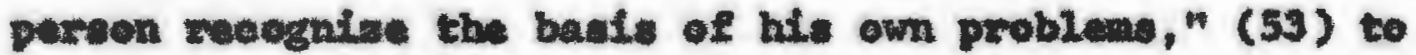
"a neans where direetion ls ohown to another," down to a "provese by which the pereon aecking halp algeovere tor himede the trae nature of his problems." (42)

Anothar paroetvad counceling as purely religfous tunction a In the following: Molnging God to men and men to ced." (50) This dofinttion is implemented with the quotation bilow:

Ithis requires meh were then the utilization of the Rogerian technique or a psychological vocabulary. Some understanding of both will help undoubtediy but unless the chaplain himself is spiritually motivated neither all the Jargon in the world nor an uni inited capacity of intelligent "grunting" will make him a effective pastoral counselor.

One Conmander sected apologetie in not rubeorlbing to a ellent-oentarnd wothod, adritting that value jedgeonte and Dorallsing ean be wod fnoorweaty, went on to state:

To considerable extent the eheplain IInde he is working with the high achool delladuent. Ios ean only be just so mon-directional when we ate worlug with a 45 or 35 (in one case a 27 ) GCT. (40)

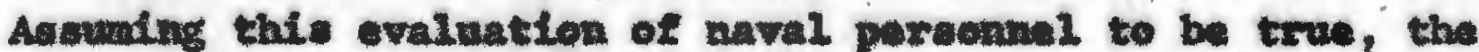
quetion arises as to how effectiv a halping rolathonhtp can

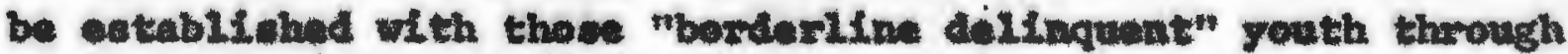

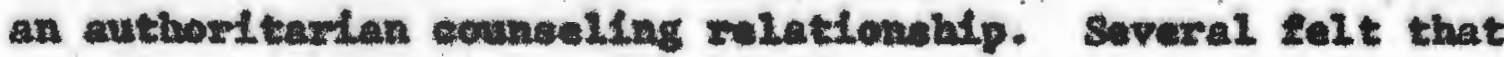
the use of "benefletal dectt" wae good procedure Lor, "the 
directing of an Individuel, throagh subtle questlon to the solution of hls problem. - the Individual thus thinking bie

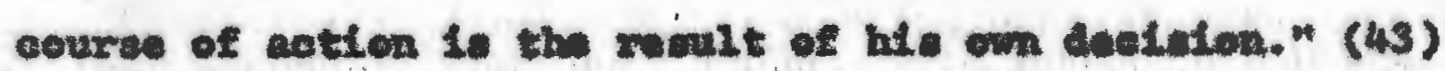
Fron these definithens and a comparieon of thatr reoponses to part (2) of this quethornal in, the Comancers and Captains torded to be leas diroetwe than the two lower ranke.

A earecul ovaluation of th dotivition given by the Lieutenant cananders mwealed that twonto-two gave rathicr


blp hingelf" type, and wang of theas contalned such terns aes encouragenont, advies, wegertion, presoription, and recomendaton, and tonded to be problen-centered rathor than prowcentexed. Mtrtecn otroesed the nature of the comacling relatounhtp patting nore importano on the intermporwonal appest.

Other aspecte of sowneeling naved by the Commandere were: ersetwe and sypathetle Letuning (65), helping councelee to halp himoolf and understand hinell. (66). One ehaplain quotud Wape ontes in defining counseling as "oplritwal convorention" Indleating a sense of commication In depth (119) and another ohannelled he decintelon to religlowe comalling as, "guidanes of a client towand perwonal Integretion, eoclal adfustwent and optrtenal orlentetion," (99) adding that he was not Intweseted in any othar lef of counsel-

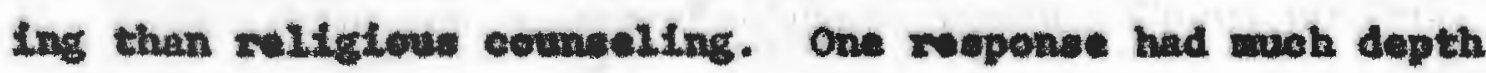
and lo worth guoting in t to ontroty: 
I think of counseling as a ereative, educational process, releasing the inner prings of motivation in personality toward high religious, moral and social goods and values; and as process involving techniques which, when applied, caable the counselee to unburden himself of an undue cones of guilt, or frustration, and sind hinself stronger to face Iffe courageously, sanely and with moral integrity, etrengthened by the personal confidence inspired by the counselor in himself, and, as it ang be, in selfgicas faith in cod, (87)

One-hale of th 50 Hewtanante gave rather anpertelal definitions, weh as: a teabriqu of problem molving, or helping others to help thamedves, one hospital chaplain weote:

the attempt to alnieter to the inner coul of the coungale as a patbor. Dot to condenn or judge;


depth. (137)

Seven reaponeen recogatred the inportanoe of MLetonIng" though they Inoluted the noed to gulds, advice and give "Intelligent direction" and argection. One Lieutenant adaitted that defining connseling was a tough question bet weat on to state that 1t, "If eartainly lending a arapathatic ear, but it is aloo ocomateating the Chxistian answer to man' dileana." (161) others reforced to cotunalling as: a process of ocmunicatlon, vexbel and non-verbal $(159) \mathrm{h}$ and guldanas to greater alf-confidenee and deeper inofghte of the proble Irvolvement (172), at the cutire group, the Ifeutenante were meet direetive in thel definitions. 
SUMMARY AND CONCLUSIONS

This study has exanined seme of the dyamia Lactors revelent to the chaplatn's role a a councelor in the Ravy. The navy chaplati has been viowed withis the franework with which he wortes, the parsennel with whom he worke, and has been givon a mbjective look at himsele a bo views hie minleter. In the flret ehapter It was obsexved that there are certain fwadanantal factore within the structured aliltary organtwation whteh impinge directly or indtrecty on hil role as counabler. While there are soane similarities between elvilian and allitary counceling, there are valid dfferences which warrent sted and understanding. Thio 10 apheld by many chaplain who have had civllian cxporience before enterIng the cervice and are camillar wh both areas.

The etrict eathort tative environmant of the Navg, Ite geographical divarelty and wobllity present many case type Loads quite different in namber and scope fron thoee encountered in civilian 1ife. The civilan elergyan to repponuble only to hle own chureh organtsetion. The navy ehaplatn Io beth the represeatativ of his orn chureh and of the government as comiasioned offleer. It may be true that hanan nature 1. bastoully the same, bat dffering enviroments of ten add to the mubar and types of probleme.

$A$ study of the value atructure of saval parsonnel in chapter two showed another Indication that we are exporieneing 
a moral rovolution anong the youtb of this goneration. symptomatic of this is the stora of articles appeariag in magarines and perlodicals ceneeraing the breakdom of morals In our nation today. Such titlos as Sex on the Carpus. The jittary Generetion, The Ralugtant Povolution, The Motsul Generation all bear witnes to the lonellnese, the dleenchentment, and the confusion of today's youth in search of cale-idontity and a value struetrure for this present age. Eonontially, navy peroonnel are no different erom civilians in this rugard. This inplies that as teachers, couneelore, or ohaplafne, we all must take oloser look at oureelves and what we are imparting to the youth of today through our ections. It calle for a wore intense etudy of the dymance of pareonality and the reesits of a growling body of research for us to achleve incight and understanding of ourealves and those when we enownter in thls holplag nelatienoulp. The response to the surveg quectionnalve wa highly eneouraging. It revealed a serlous interest in the work of counbeling in the Navg, at well as an swarenese of the Inoreaning demand for otudy in this flatd and a growlag realisation of It inportance in our complex and ahanging coctety. Meny cheslain remarlond on the quentionnalre of thair intereat In such a poject as this, and one vistully hoped that the reovite of this quoticanaire would be morn enlightening than blanketing our undombtadly often ignorant mannor and nothods. 
The elrst section of the questionnalme revealed a wide range of diveraity in reaction to the counveling techulquee ruprecented. It aleo indieated an unfaniliarty of many chaplatis with acoptable counseling geal appoved by

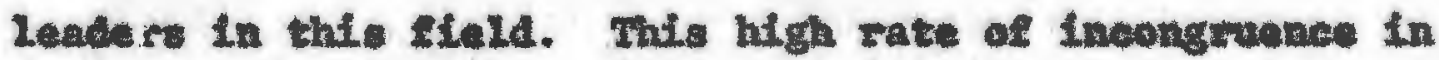
many of the reoponses reflects this weaknes and points up the noed for moxe introve in-service edweation and training. Whth such a broad range of sowe 42 different chureh background and atrarat of edscattenal expretence, the need for wore entfornity in tratuing for the councelling role is constiered rteal.

the relatively heavy coumeling loed ruported by this -tudy along with the variety of problems onoountered, ahows tho noed for profeesional competenes in this theld. The Level of graluate acadenie training of navy chaplatns as raported in this study is quite low. of the 172 ahaplaims reoponding to this quation, only 64 . had reetived poot-gradrate training or had taken atnimu of acadeale courses in counveling or related telds. If this reported porcentage could be futtiflably axtended to the entire chaplatin carpe, It worald Indicate that oaly 37 per cent of the dheplating on active duty today mere to be considered adequately trained Eor this sole.

Few of the definttion offered by the ohaplatne in reeponse to the Last eection of the quettlonmatre obowed ang deep underotanding of the counceling relatiountp. Many of 
the definitions were superficlal. Stock phraess and ellehes were empleyed relegating ceanueling to "helping people belp themelved" The reoulte ranged all the way froa the Incteontal and the Inuigniflcant to principlee which wet be guldelines to sucesefful ecuneding. The response to the etret iection of the quetionnatre coreclated well with the Gefinttions effered by the ehaplatne. The Captains, Ith

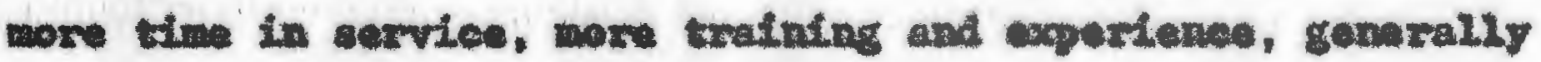
hat a trend teward ellent-oenterednes in their vlew of thamelves. The degee of directive-anthoritarlan proeesoes In equaveling deoreaced in dixpot watio with rank in the thavy and exparlonae. The quallty and nature of the counselIng ectndtion could be tairly well powdeted by the DLwetive seor attained by the chaplatn.

While the difenxnew it wifgious affillations as

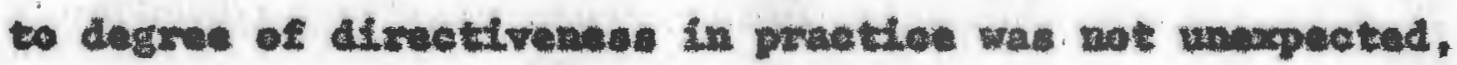
the Roman Gatholte chaplain' recponses revented more of a

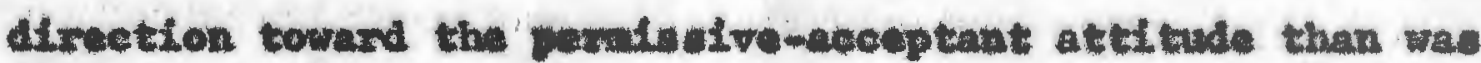
expected. This could poedbly tadeate a trond which has been brought about in secent peare through inerveced enphate on somseling in Cetholic educattral inetitutions.

Fwon the remulte of thls studg, aeveral zecomandations are oflered which, It is telt, would lead to growth

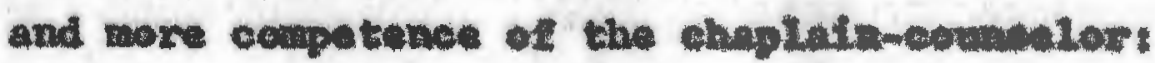

(a) It is recemended that acunealing suninars be conducted on a Lecal Leval at anjer comands rather than on 
a detwict levi, to afford more choplatno an opportunity to attend. These area seminars could be oxganiaed in copperation with cemneelor-educatore if avilable or competent civilian authoritiea. Thase abould be beld on a monthly bants with intenee study expected.

(b) Dubleation of articles or a quartarty pertodical dealing with contemporany research and 11 terature in this expanding fleld of councling. Protesoional contributions troc leading man in counoeling could be utillesd. To asaict in this, the Chaplalns Diviolon could sotablish liason with such organinatione as the Amariaen Pereonal and Guldance Anoplation, the Anarican Poyphologloal Ansoctation, and Pastoral couneling oxgantzationa. Though numbross books In this fleld are avallable, very little is pablishad throegh the havy on this wabjoet.

(c) Inorease the quantity of tim allotad to a vtady of ecunseling at the Ohnplaine Indoctrination Sobpol, Nevport, trow one day to at least a wael. The carrlewlum abouid Inalude a more intenaive otudy of the beaic prinatples of

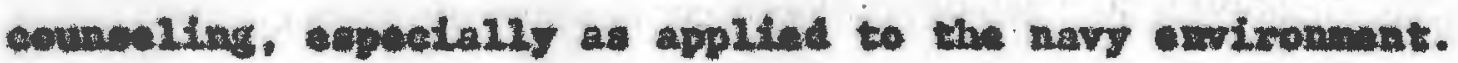

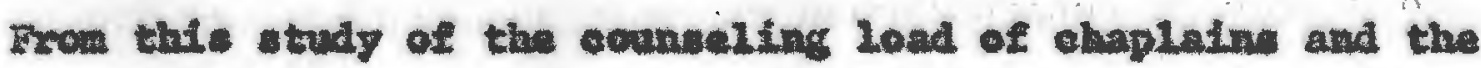
perconal experlence of this researoher, conseding in the Caily work of the chaplain demands up to 70 per cent of hie work 1oad. Since cownisting is so Importent a part of the ohoplain's ninietny, were properation for this mole should be glven to the nu chaplet coulng Into the serviee. 
(d) Provide opportanity, on a loeal level, for

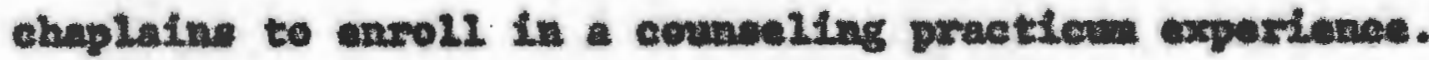
This could be axranged through now-by unferattles, of under the direetlon of adequataly trainod ehaplains. In this cenneetion, the poetibilfy of Including a select nuber of chaplain in the IDEA counceling Institute glven during the ourmer at many miverelties throughout the country should be lnvestigated. Thio would be in addition to the alrwedy operative pot-graduete duty-qudor-instraction.

(a) That the Chaplatno Diviaton connider proparing a mamal comprehenstve enough to provide gutdaline for all chaplaing. Such a manual would Include an up-to-late bibliography relating to all oubjecte whteh confront the ehaplain In his role as councelor. This could be accomplishod through the establishlng of research teamo such as are now uttliesd In connection with the laadershlp Progran.

(2) Invetigation of the practical use of group coumealing in other than institutenallsed comands. A atudy of group dymandes and proeeduree covid bo included in the area achinare or in the post-graduate currfoulun. The aature and Intcoulty of the chaplain's counouling lood Indicate a reh postlility for the use of group counseling on naval stations and ohipe as well as In rohabilitation centere and naval boopltale.

It is Lelt that the reoults of this stady reveal some Atal Inolghte for the chaplaine corps an woll as the 
72

individual chaplain. The inorsalng Interest in cosmentug indicated by the response to this study and the anovuraging manner in which it was received by the chaplain participating Indicate that the need for Implemented training in connecting In the Nay y is very desirable. The returned questionnaires reveal a willugmese to chare experlenese in order to promote offlefoney and effectiveness in the counseling furetton. 
BIBLIOGRAPEY 
BIBLIOGRAPHX

A. Books

Adler, Alfred. Uhieretanding Bman Natrux. Greenrich, Conn.: Fawe EE Pablidetron, inc., Eremier Booke, 1957.

Arberlw, Dugald s. Conneling: An Introduetion. Boston: Altre and Baeon, Ine, 196r.

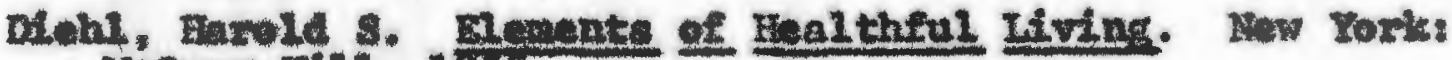

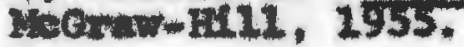

Ginubas. Wil (ed.). Volven and Ideald of Ameriean Youth.

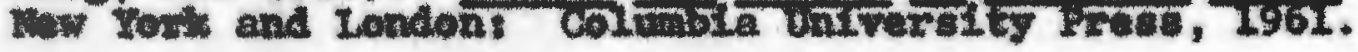

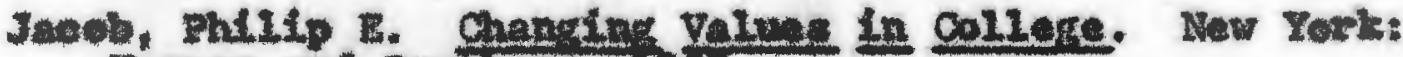
Eaper and Brother, 1957.

Johasen, Pasl. Pereholoty of Peotorel Gare. Now Torit: Abingdon Prean, LSs.

3un. C. C. Modern Man in Search of a Soul. New York: W. W. Morton and Catpan7. I959.

Klexhogeand, Sonen, Iraining in Cortatiantsy. (miter Lewrle, trane.) Loncoa! Gxtore Ualversity Prese, 1942.

May, Rolle. The Axt of Coungaling, Rahwlle, Tena.

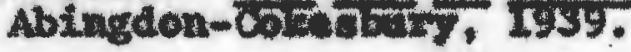

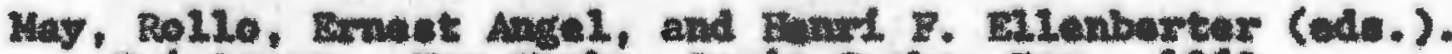

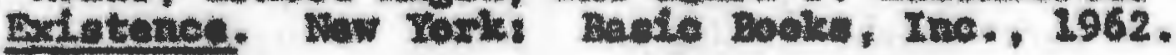

The Now Englidh Btble. How Tostenent. axtoxt Datraralty Prese, Combridge Universt by Feas, 1962.


nooghton-likexin 60,2947 .

- 6. Loct. Becoming a Persen. Boston: Honghton-Mieflin

Tillich, Pavl. The Protestant Bra. (Jmane I. Mams, trane.). Chicago: The University of Chicago Prwes. Phoenix Boolis: Abridged Ed., 1957.

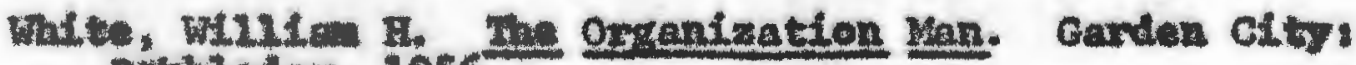
Bublediay, 1956. 


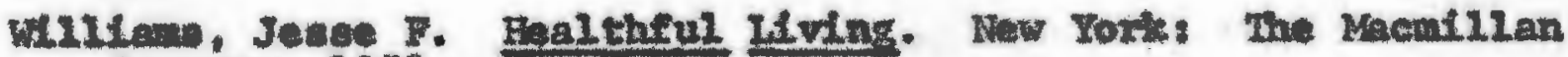
Company, 1953:

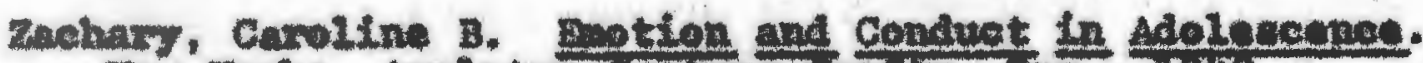



\section{B. PERTodratis}

Jacob, Eulltp E. " college Horale," Compoolitan, CXIII (Septenber. 1957).

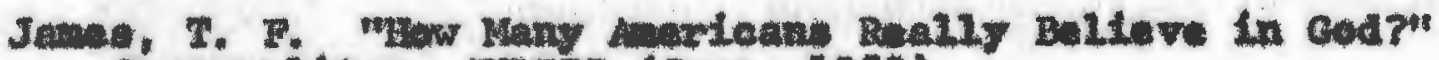
Copopolitan, GxirII (June, 1958 ).

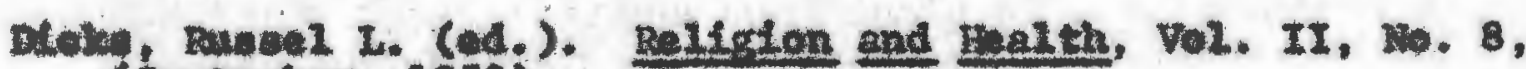
(September, 1953$)$.

Fill taner, Swrand. "The Perebologleal boterwitanding of ReLIglon," Goeer Qderterly (Jamary, I947), Vol. XXIV, wo. I.

Eoover, J. Hgas. "Countarattack on Jwentle Delinquanoy," Int weis (0otobor 26,1958 ).

Rumars, H. H.; and D. H. Radler, Moonage Attd tuded," selontefte taeriean, cxcvIII (Jane, 1958).

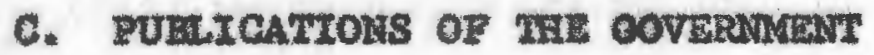

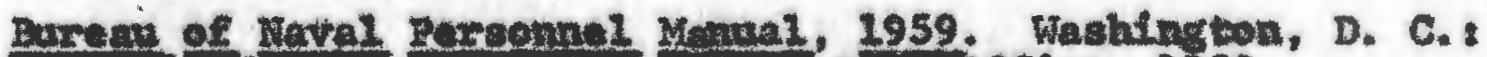

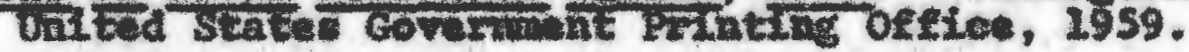

Chaplaitu' Namnel. Havpers 15664-B. Wephingten, D. C.:



Bor Men Only. 8. 8. Navy and Marine Corpw Character EdueaEton Series I. Wachington, D. C. J. S. Govemmint Pwinting office.

Grant, James W. "Ihe Penitent-Glergyan Puivilege in Military Iaw," Navr Chaplains' Bulletin, NavPer. 15020 (Fall, 1959). Waskington, D. C.: U. S. Governwent Printing oftice.

Maral Leadership. NavPers 15890, Wahington, D. C, v. s. Covernment Printing office. "The Protection af Hoxt standard: and Character Education Program." 
Ins Yamal of Corts-Yart1al, ․ S. 1952. Wachington, D. C.I U. S. Govermment printing diflee.

gur. Marel and Spiritual growth Here and Now. v. 8. Mav


91962, U. S. Govermant Printing offlce.

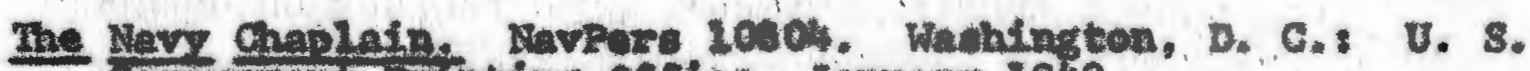

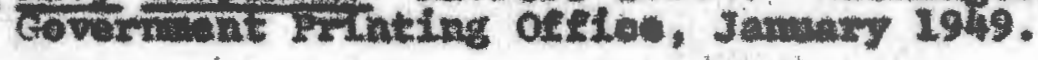

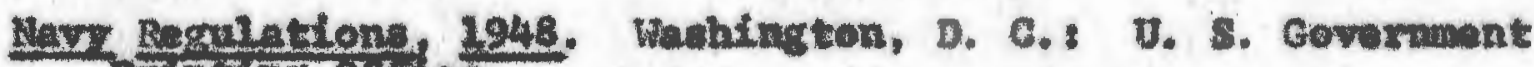
pintag oxtac.

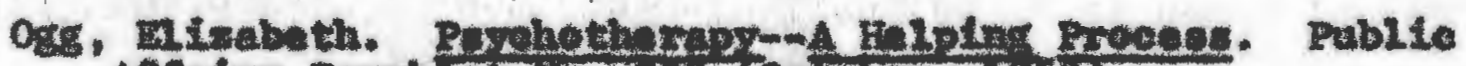

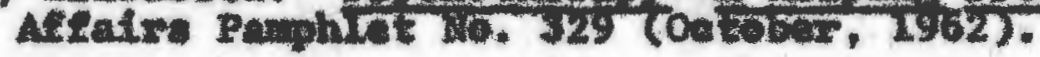


AFPENDX A 
SURVEY OF COUNSELING IN THE NAVY

Denomination Rank Years in Navy

1. Please indicate, by placing a check mark in the appropriate column at the right, how. you as a counselor, feel about the statements that follows

a. Some individuals who come to you are incapable of establishing appropriate goals and values.

b. A counselor should prescribe the best solution after diagnosis of a client's problem.

c. A counsel or should register disapproval of immoral acts revealed by a cllent.

d. A counselor should accept what a client says at face value.

- A counseior should concentrate more on what is being said rather than why it is said or how it is expressed.

f. Good rapport may be facilitated when the counselor expresses approval of something the client has said or done.

9. Under favorable conditions, a person can develop in a direction beneficial to himself and society.

h. It is helpful to a client when a counselor clarifies a problem by reference to his lown personal experience.

1. What a client reveals should not be judged by the counselor's own system of values.

1.. The stated problem of a cllent is not always the real difficulty.

k. A counselor should not express his own feelings or interpretations to a client.

1. Progress in counseling is alded through encouragement and the bullding up of confidence in a client. 
2. In the column at the right, indicate to the best of your memory, the frequency the below problems were brought to you for counseling.

a. Inability to adjust to navy life.

b. Marital difficulties (non-support, desertion, Infidelity, etc.)

c. Indebtedness.

d. Alcoholism (drinking constituting the major problem).

e. Homesickness, loneliness.

f. Anxiety, depression (emotional disturbances).

g. Disciplinary problems (captain's mast, court martial, etc.)

h. Pre-marital (promiscuity, preparation for marriage, etc.)

1. Religion (spiritual concern, doubts, guilt feelings, etc.)

j. Education (occupational, career and academic planning)

k. Other.

3. List graduate level courses you have taken in counseling or related flelds.

4. What percentage of your counselees returned for a second session?

3. What percentage returned for more than two sessions? $\%$

6: In your own words, briefly state below what you believe counseling is. 
APR BNDIX B 
COPY OF COVERTMG LETTER SENT WITH SURVEY QUESTIOMMARE

17 Jomaxy 1964

4 dear Chaplain,

In. enelosed Survey of Counseling in the Navy to being malled to a representative number of Kavy Chaplains on active duty. This survey is part of a study I am making in counseling at the University of Rhode Island. It would be greatly appwelatad if you would opare a few minutes of your time to respond to this aurvey.

It te very brief and can be completed while you are having your morning coffee. It il not neceseary to sign your nam. It Is only requested that you complete the items thoughteully and as far es possible, somurately.

As the work of counseling is a contantly evolving process and as its requirenents are continually being raised, it should be of great interest to learn what concept Navy Chaplains have concerning their role as counselors. The implications of this survey could have soma effect in future post-graduate instruction and counseling aeminar training. When this study is complete, the results will be forwarded. to the Chaplains Division; and If ceepped, will possibly be made evatlable to all Navy Chaplains.

Your Individual reaponse to this suxvey will be of great aedstance and importance to this study. Please seturn the aurve in the enclosed, self-addressed envelope.

I want to thaik you in advane cor your cooperatton and I will apprectate your bulp in this vital project.

\author{
sinoerely youre, \\ THOMAS B. UBER \\ LCOR, GRC, USN
}

Enel:

(2) "survey of Comnedtug in the Bavy" 
APPENDIX C 
COPY OF COVERING LETTER SENT WITH SURVEY QUESTIOMATRE

17 Jemangy 2964

4 dear Conplatin,

Th. enclosed Survey of Counseling in the Navg is being mailed to a representative muber of Navy Chaplains on active duty. This survey is part of a study I an making in counseling at the Iniversity of Rhode Ialand. It would be greatiy apprwelated if you would epare a few mimutes of your time to respond to this surver.

It Is very brief and can be completed while you are having your morning coffee. It is not neececary to sign your name. It Lo only requested that you ecmplete the itens thoughtfuliy and as Lar as posible, scturatrily.

As the vork of counseling 10 constantly evolving process and as ito requirements are continualiy being raised, it chould be of great interest to leam what concept Navy Chaplains have concerning their role a counselors. The implications of this survey could have souse effect in future post-graduate instruction and counseling seminar training. When this study is complete, the results will be forwarded to the Chaplains Division; and It coeppted, will posaibly be made evallable to all Navy Chaplaine.

Your Individual reapones to this ourvey will be of grent assiotanes and importanes to this study. Please seturn the anvey in the enclosed, celf-addressed envelope.

I want to thank you in odvanes for your oopgratlon and I wll appreclate your blo in thle vital projece.

\author{
Sinearely goure, \\ TEOMAS B. UBER \\ LCD, Gac, USN
}

Inan:

(1) "Survey of Commelling in the Navy" 
SUMARY OF TOTAZ RESPONSES TO PART I, SURVET QUESTIOMAIRE

\begin{tabular}{|c|c|c|c|c|c|c|}
\hline Itees & $\begin{array}{l}\text { Strongly } \\
\text { Atres }\end{array}$ & $\begin{array}{l}\text { Mildily } \\
\text { Agree }\end{array}$ & $\begin{array}{l}\text { unde- } \\
\text { elded }\end{array}$ & $\begin{array}{l}\text { MLldiy } \\
\text { DLearese }\end{array}$ & $\begin{array}{l}\text { Strongly } \\
\text { DLearree }\end{array}$ & Total \\
\hline a.* & 84 & 55 & 3 & 19 & 12 & 172 \\
\hline b. & 25 & 35 & 28 & 36 & 67 & 271 \\
\hline e. & 17 & 27 & 12 & 49 & 67 & 172 \\
\hline 4. & 10 & 30 & 5 & 45 & 81 & 171 \\
\hline e. & 14 & 15 & 6 & 58 & 75 & 167 \\
\hline e. & 28 & 77 & 20 & 28 & 15 & 168 \\
\hline 8. & 202 & 52 & 7 & 4 & 1 & 165 \\
\hline h. & 8 & 48 & 21 & $\mathbf{5 5}$ & 40 & 172 \\
\hline 1. & 65 & 47 & 4 & 32 & 17 & 165 \\
\hline s. & 152 & 18 & & 1 & 1 & 172 \\
\hline $\mathbf{k}$. & 30 & 68 & 10 & 53 & 10 & 171 \\
\hline 1. & 117 & 46 & 5 & 2 & 2 & 172 \\
\hline
\end{tabular}

The 1tene for the above auvey are Ilsted on the questionnaire, Appondix (A). Not all of the 172 chaplains filling out this aurvey answered enoh Itw, as the total figures indicate. 
APPENDIX D 
DISTRIBUTION OF COUNSELING SURVEYS RETURNED BY CHURGH AND RANK

Ghurch Affiliation

Roman Catholle

Nethodist

Southern Baptist

Lutharan

Prebjterian, USA

Presbyterian, US

American Baptist

Episcopal

United Chareh of Christ

DLsciples of Christ

Jewish

Ascenbly of God

Bvan. v. Brathron

Claurch of Cod (Andron)

Ch. Mise. Alliance

Congregational

Assoc. Gos. Chureh

Brethren

Chrietlan Solenes

Cons. Beptist

Cumb. Presbyterian

Eastern Orthodox

I. F. C. A.

Nazarene

Reformed Ch. In An.

None apecified

No church or rank

Total
GAPT CDR LCDR LT TOTAL

\begin{tabular}{lllll}
1 & 7 & 6 & 11 & 25 \\
7 & 6 & 6 & 55 & 24 \\
1 & 4 & 8 & 6 & 19 \\
3 & 6 & 6 & 2 & 17 \\
2 & 4 & 7 & 2 & 15 \\
0 & 0 & 4 & 2 & 6 \\
4 & 1 & 3 & 5 & 13 \\
1 & 1 & 4 & 2 & 8 \\
0 & 1 & 5 & 1 & 7 \\
0 & 2 & 2 & 1 & 5 \\
0 & 2 & 1 & 1 & 4 \\
0 & 0 & 0 & 2 & 2 \\
0 & 1 & 1 & 1 & 3 \\
0 & 0 & 0 & 2 & 2 \\
0 & 1 & 1 & 0 & 2 \\
0 & 1 & 2 & 0 & 3 \\
0 & 0 & 0 & 1 & 1 \\
0 & 0 & 1 & 0 & 1 \\
0 & 0 & 1 & 0 & 1 \\
0 & 0 & 2 & 0 & 1 \\
0 & 0 & 0 & 1 & 1 \\
0 & 0 & 1 & 0 & 1 \\
0 & 0 & 1 & 0 & 1 \\
0 & 0 & 1 & 1 & 2 \\
0 & 0 & 0 & 1 & 1 \\
0 & 1 & 0 & 0 & 1 \\
19 & 38 & 62 & 47 & 172 \\
\hline & & & &
\end{tabular}

